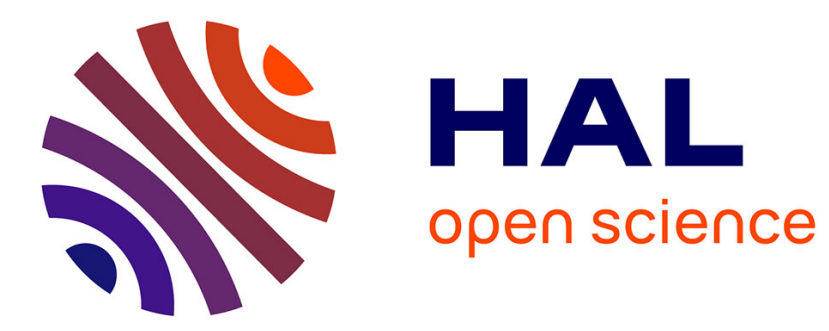

\title{
Parameter regionalization for a process-oriented distributed model dedicated to flash floods
}

Pierre-André Garambois, Hélène Roux, Kévin Larnier, David Labat, Denis

Dartus

\section{- To cite this version:}

Pierre-André Garambois, Hélène Roux, Kévin Larnier, David Labat, Denis Dartus. Parameter regionalization for a process-oriented distributed model dedicated to flash floods. Journal of Hydrology, 2015, vol. 525, pp. 383 - 399. 10.1016/j.jhydrol.2015.03.052 . hal-01178432

\section{HAL Id: hal-01178432 \\ https://hal.science/hal-01178432}

Submitted on $20 \mathrm{Jul} 2015$

HAL is a multi-disciplinary open access archive for the deposit and dissemination of scientific research documents, whether they are published or not. The documents may come from teaching and research institutions in France or abroad, or from public or private research centers.
L'archive ouverte pluridisciplinaire HAL, est destinée au dépôt et à la diffusion de documents scientifiques de niveau recherche, publiés ou non, émanant des établissements d'enseignement et de recherche français ou étrangers, des laboratoires publics ou privés. 


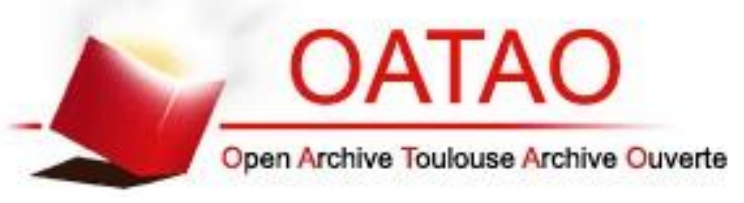

Open Archive Toulouse Archive Ouverte (OATAO)

OATAO is an open access repository that collects the work of Toulouse researchers and makes it freely available over the web where possible.

This is an author-deposited version published in: http://oatao.univ-toulouse.fr/ Eprints ID: 13873

Identification number: DOI: 10.1016/j.jhydrol.2015.03.052

Official URL:http://dx.doi.org/10.1016/j.jhydrol.2015.03.052

\section{To cite this version:}

Garambois, Pierre-André and Roux, Hélène and Larnier, Kévin and Labat, David and Dartus, Denis Parameter regionalization for a process-oriented distributed model dedicated to flash floods. (2015) Journal of Hydrology, vol. 525. pp. 383 - 399. ISSN 0022-1694

Any correspondence concerning this service should be sent to the repository administrator: staff-oatao@inp-toulouse.fr 


\title{
Parameter regionalization for a process-oriented distributed model dedicated to flash floods
}

\author{
P.A. Garambois ${ }^{\mathrm{a}, *}$, H. Roux $^{\mathrm{b}, \mathrm{c}}$, K. Larnier $^{\mathrm{b}, \mathrm{c}}$, D. Labat $^{\mathrm{d}}$, D. Dartus ${ }^{\mathrm{b}, \mathrm{c}}$ \\ a INSA de Strasbourg, 24 Boulevard de la Victoire, ICUBE-CNRS, UMR 7357, Fluid Mechanics Team, 67000 Strasbourg, France \\ ${ }^{\mathrm{b}}$ Université de Toulouse, INPT, UPS, IMFT (Institut de Mécanique des Fluides de Toulouse), Allée Camille Soula, 31400 Toulouse, France \\ 'CNRS, IMFT, 31400 Toulouse, France \\ d Géosciences Environnement Toulouse, Université de Toulouse, CNRS, IRD, OMP, 31400 Toulouse, France
}

Keywords:

Mediterranean flash floods

Parameter sets regionalization

Process-oriented distributed model

\begin{abstract}
S U M M A R Y
This contribution is one of the first studies about the regionalization of parameter sets for a rainfall-runoff model process-oriented and dedicated to flash floods. MARINE model performances are tested on a large database of 117 flash floods occurred during the last two decades in the French Mediterranean region. Given the scarcity of flash flood data, the dataset used in this study represents a large sample of hydrology and landscapes from Pyrenean, Mediterranean, Cévennes-Vivarais and Provence regions. Spatial proximity and similarity approaches with several combinations of descriptors are tested. Encouraging results are obtained with two similarity approaches based on physiographic descriptors with two and three donor catchments. There is only a small decrease of performance of $10 \%$ from cal/val to regionalization for these two methods. For 13 catchments out of 16 there is at least one flood event simulated with rather good performance. This study highlights the importance of hydrological information that is available in calibration events for a gauged catchment and from donor catchment(s) for regionalization. Moreover it is found that regionalization is easier for catchments with an apparently more regular behaviour. The most sensitive parameter of MARINE model, $C_{Z}$, controlling soil volume and water balance, is rather well constrained by the two similarity approaches thanks to bedrock descriptors.
\end{abstract}

\section{Introduction}

\subsection{Context of the issue: flash floods predictions at ungauged locations}

With the current and increasing water management requirements, prediction of hydrological variables for ungauged basins (PUB) has been singled out by the IAHS as one of the important challenges for the hydrological community (Sivapalan et al., 2003). Determining peak flow values of various return periods and the associated uncertainty is an indispensable prerequisite for planning mitigation measures which reduce or even prevent flood damages (see e.g. (Pilon, 2004)). This is particularly true in the case of flash floods, often constituting extreme catchment's response. They are one of the most destructive hazards in the world (Jonkman, 2005) and they caused casualties and billions euros of damages in France over the last two decades (Gaume

\footnotetext{
* Corresponding author at: IMFT, Allée du Pr. Camille Soula, 31400 Toulouse, France.

E-mail address: pierre-andre.garambois@insa-strasbourg.fr (P.A. Garambois).

et al., 2009). Regarding response time decreasing with catchment areas, small ungauged catchments $\left(\sim 10 \mathrm{~km}^{2}\right)$ are often the most destructive ones as for the extreme flash flood event of September 2002 in the Cévennes region (France) (Ruin et al., 2008).

In the literature, various approaches, in terms of perception and parameterization of the dominant hydrological processes, are proposed for flash flood events modelling and/or prediction (Braud et al., 2010; Moussa et al., 2007; Roux et al., 2011) among others for the North-Western Mediterranean region). Illustrating the current shift toward distributed modelling, these models often take advantage of available data in order to assign spatially distributed forcing as well as distributed catchment parameters.

The problem of rainfall measurement/prediction uncertainty is particularly crucial when attempting to develop flash-flood regionalization methodologies, especially on fast-responding catchments involving several difficult problems, such as structural, parametric or data uncertainties. For some catchments studied in this paper, rainfall spatial and temporal organization has been discussed in Garambois et al., 2014 and in Garambois et al., 2015 the latter also investigating the impacts of rainfall errors on the 
response surface and the performances of MARINE model. Systematic propagation of errors on forcing and initial conditions through a hydrological prediction system would be of prior interest. However, error structure itself appears to be complex and the development of error metrics, for example from geostatistical techniques, is still a research topic (e.g. (Delrieu et al., 2014a, 2014b)). In the present study most flash flood events are modelled with radar rainfalls recalibrated on raingauges with a spatial resolution of $1 \mathrm{~km}$ at 5 min time steps (hourly interpolated raingauges otherwise) (Garambois et al., 2014), rainfall moments integrated over storm duration (e.g. (Zoccatelli et al., 2011)) are reported in Appendix A, Table 1.

The process-oriented distributed model MARINE (Roux et al., 2011) has already been tested without parameter calibration on 2.5-99 $\mathrm{km}^{2}$ ungauged catchments in the Cévennes region for the purpose of dominant processes analysis (Braud et al., 2010). Simulations were assessed using post field estimates of timing and maximum discharge of peak flow and the authors show the importance of soil characteristics and initial water content before a flash flood event. From those studies, it appears that a better knowledge about the dependency of hydrological processes on catchment properties can be useful for tailoring physics-based hydrological models for predicting floods in ungauged areas.

In the present study, the soil saturation is systematically initialized from a continuous water balance model for each catchment as performed by Roux et al. (2011), Tramblay et al. (2010), Vincendon et al. (2010). Using a process-oriented model such as MARINE model on a mesh at a few hundred meters resolution, i.e. on a finer grid than rainfall's one, allows coupled modelling of non-linear hydrological processes for flash flood generation at the scale of catchment areas of a few hundred square kilometres. Indeed the SIM model does not take into account the kind of flow processes giving rise to flash flood hydrograph.

As a matter of facts, it is not possible to calibrate data-driven models at ungauged locations. Hydrologists have therefore been attempting for 40 years to develop estimation methodologies describing rainfall to runoff process without calibration (see e.g. (James, 1972)). Originally dealing with hydrological regime classification and catchment grouping (e.g., (Gottschalck et al., 1979; Pardé, 1933)), the term regionalization was later extended to the transfer of rainfall-runoff model parameters from a gauged donor catchment to ungauged ones. Transferring parameters is often performed in the case of geographically close catchments. However, nearby catchments can present significant contrasts in terms of physiographic properties and hydrological behaviours, especially during floods or even flash floods involving rapid responses and highly nonlinear and coupled physical processes in time and space as their generating storm (Borga et al., 2008; Garambois et al., 2014).

1.2. Regionalization methods: a compromise between available physical descriptors, stream gage density and rainfall runoff model features

Among the numerous techniques proposed for the regionalization of catchment model parameters, generally for continuous (conceptual) rainfall runoff models, three kinds of approaches can be distinguished with their specific advantages and inherent drawbacks (Oudin et al., 2008): regression based methods, geographical proximity, and similarity methods. Several regionalization studies mostly for rather large datasets are briefly presented in (Table 2).

Regionalisation problem for catchment hydrology has been explored for several (instrumented) regions of the world with different catchments datasets without reaching a consensus on the method, the modelling options of the hydrological process or the physical descriptors to use. Even for large datasets, modellers' choices, rainfall to runoff model's structure and parameterization (Bárdossy, 2007; Kay et al., 2006), or physical descriptors availability (Merz et al., 2006) influence regionalization performances and the possible physical interpretations.

A comparison of the three methods mentioned above with two lumped conceptual models (GR4J and TOPMO) shows that in France, where the gauging network is relatively dense, spatial proximity provides the best regionalization results for a 913 catchments dataset (Oudin et al., 2008). It is argued that the failure of methods based on catchment descriptors might be attributable to the lack of key physical descriptors of soil hydrology, and that there is room for progress by learning how to merge the different methodologies. For example, for a regionalization study in Switzerland built on 140 catchments and tested on 49 catchments, the most favourable regionalization results are those obtained by combining nearest neighbour, spatial krigging of parameters and regression (Viviroli et al., 2009).

Those regionalization studies are generally performed with continuous models on mesoscale catchments. Tackling the problem of flash flood regionalization on a large data set with an event-based rainfall-runoff model, process-oriented and spatially distributed has not yet been documented in the literature to our knowledge. Following results of other regionalization studies on very large datasets (Table 2), the choice is made not to explore regression methods given the lower performances compared to other methods using donor catchments for entire parameter sets. As shown later, single correlation coefficients found between calibrated parameters and physiographic attributes are not high enough to ensure good predictions and build regional regressions to calculate model parameters at ungauged location. Moreover, calibrated parameter sets contain some compensation of measurements and model errors.

The present study uses the MARINE model which is spatially distributed and as exposed in Section 2.2, unique multiplicative constants are applied to parameter maps (Bandaragoda et al., 2004; Francés et al., 2007; Pokhrel et al., 2008; Roux et al., 2011; Vélez et al., 2009; Vieux et al., 2003). Calibrated parameter sets composed of calibrated multiplicative constants will be transferred from gauged catchments to ungauged ones.

\subsection{Scope of the paper: regionalization with an event physically based distributed model}

The present paper seeks to explore the potential of a processoriented distributed model for regionalization in the case of a large and various flash floods dataset. It focuses on flash floods in the French Mediterranean region which is quite complex in terms of soils, geology and flood-triggering rainfall patterns. Storm variability along with catchment properties engenders nonlinear physical processes, which makes the understanding of flash floods not straightforward, especially when catchments are small with moderate dampening effect on rainfall signal. In that case, catchment behaviour can be very different from one flood event to another and compensations with hydrologic model parameters can be more difficult; particularly for longer time scales. The core idea of the research published here is to evaluate whether a physically based distributed hydrological model can be used for predicting flash floods at ungauged locations within the French Mediterranean region. In the context of Mediterranean flash floods two questions can be formulated: how is catchment's uniqueness reflected in a regionalization procedure (Wagener and Wheater, 2006) and how and which information is best transferred (Merz et al., 2006)? Regionalization methods are elaborated in view to predict flash floods for ungauged catchments. Its originality lies in: 
Table 1

General characteristics of the 117 flash flood events dataset. No rainfall indices are calculated for 8 events on the Salz since only one raingauge is available. Initial soil moisture is 50 for the Réal Martin, Nartuby, Gapeau and Aille catchments since we do not dispose of SIM data for these 4 locations.

\begin{tabular}{|c|c|c|c|c|c|c|c|c|c|}
\hline Catchment & Area $\left(\mathrm{km}^{2}\right)$ & Event & $\begin{array}{l}\text { Initial soil } \\
\text { moisture (\%) }\end{array}$ & $\begin{array}{l}\text { Cumulated } \\
\text { rainfall }(\mathrm{mm})\end{array}$ & $\begin{array}{l}\text { Delta1 } \\
(-)\end{array}$ & $\begin{array}{l}\text { Delta2 } \\
(-)\end{array}$ & $\begin{array}{l}\text { Specific peak flow } \\
\text { discharge }\left(\mathrm{m}^{3} \mathrm{~s}^{-1} \mathrm{~km}^{2}\right)\end{array}$ & $\begin{array}{l}\text { Lag } \\
\text { time (h) }\end{array}$ & $\begin{array}{l}\text { Runoff } \\
\text { coefficient }(-)\end{array}$ \\
\hline Agly & 216 & 04_12_2003 & 57 & 81 & 0.67 & 0.39 & 0.69 & 4 & 0.44 \\
\hline Agly & 216 & 21_02_2004 & 56 & 50 & 0.94 & 0.85 & 0.25 & 5 & 0.30 \\
\hline Agly & 216 & 15_11_2005 & 70 & 97 & 0.98 & 0.80 & 0.70 & 3 & 0.56 \\
\hline Agly & 216 & 11_10_2010 & 43 & 176 & 1.03 & 0.84 & 0.91 & 5 & 0.47 \\
\hline Agly & 216 & 15_03_2011 & 60 & 172 & 0.99 & 0.77 & 1.08 & 5 & 0.71 \\
\hline Cesse & 231 & 27_02_1981 & 58 & 91 & 0.91 & 0.75 & 0.62 & 7 & 0.90 \\
\hline Cesse & 231 & 02_12_1987 & 60 & 317 & 1.03 & 0.70 & 1.99 & 10 & 0.67 \\
\hline Cesse & 231 & 18_10_1994 & 60 & 139 & 1.00 & 0.92 & 1.58 & 6 & 0.30 \\
\hline Cesse & 231 & 13_10_1996 & 60 & 117 & 1.00 & 0.93 & 0.56 & 10 & 0.35 \\
\hline Cesse & 231 & 04_12_1996 & 48 & 249 & 1.02 & 0.77 & 1.13 & 9 & 0.47 \\
\hline Cesse & 231 & 03_11_1997 & 50 & 50 & 0.95 & 0.66 & 0.30 & 4 & 0.20 \\
\hline Cesse & 231 & 11_11_1999 & 55 & 254 & 1.05 & 0.92 & 1.30 & 8 & 0.35 \\
\hline Cesse & 231 & 04_12_2003 & 62 & 73 & 0.95 & 0.94 & 0.64 & 7 & 0.90 \\
\hline Cesse & 231 & 15_11_2005 & 61 & 131 & 0.95 & 0.88 & 1.13 & 9 & 0.78 \\
\hline Cesse & 231 & 28_01_2006 & 58 & 133 & 1.00 & 0.95 & 1.13 & 6 & 0.74 \\
\hline Cesse & 231 & 16_03_2011 & 51 & 299 & 1.06 & 0.86 & 2.27 & 4 & 0.70 \\
\hline Gardons & 545 & 13_10_1995 & 62 & 177 & 0.85 & 0.57 & 2.60 & 4 & 0.51 \\
\hline Gardons & 545 & 10_11_1996 & 56 & 220 & 1.03 & 0.69 & 1.28 & 6 & 0.39 \\
\hline Gardons & 545 & 17_05_1999 & 56 & 133 & 1.08 & 0.67 & 1.30 & 5 & 0.48 \\
\hline Gardons & 545 & 28_09_2000 & 51 & 203 & 1.02 & 0.78 & 1.45 & 6 & 0.23 \\
\hline Gardons & 545 & 14_03_2002 & 57 & 66 & 0.58 & 0.47 & 1.23 & 5 & 0.37 \\
\hline Gardons & 545 & 08_09_2002 & 48 & 284 & 0.79 & 0.86 & 6.69 & 4 & 0.39 \\
\hline Gardons & 545 & 18_10_2006 & 56 & 237 & 1.07 & 0.66 & 2.65 & 10 & 0.36 \\
\hline Gardons & 545 & 22_10_2008 & 47 & 139 & 0.62 & 0.47 & 1.98 & 5 & 0.24 \\
\hline Gardons & 545 & 31_10_2008 & 56 & 75 & 1.04 & 0.66 & 1.93 & 10 & 0.90 \\
\hline Gardons & 545 & 10_11_2011 & 57 & 258 & 1.01 & 0.72 & 1.91 & 7 & 0.90 \\
\hline Herault & 786 & 18_10_2006 & 65 & 154 & 0.90 & 0.88 & 0.98 & 12 & 0.61 \\
\hline Herault & 786 & 02_11_2008 & 64 & 157 & 0.87 & 0.76 & 0.59 & 8 & 0.55 \\
\hline Herault & 786 & 15_03_2011 & 57 & 263 & 1.01 & 0.89 & 0.50 & 17 & 0.51 \\
\hline Herault & 786 & 03_11_2011 & 58 & 312 & 0.93 & 0.88 & 1.34 & 8 & 0.59 \\
\hline Orbieu & 263 & 12_02_1990 & 57 & 157 & 1.06 & 0.85 & 0.87 & 7 & 0.23 \\
\hline Orbieu & 263 & 05_05_1991 & 57 & 122 & 1.07 & 0.80 & 0.57 & 8 & 0.38 \\
\hline Orbieu & 263 & 26_04_1993 & 56 & 92 & 1.00 & 0.94 & 0.49 & 10 & 0.37 \\
\hline Orbieu & 263 & 23_12_1993 & 57 & 69 & 1.10 & 0.68 & 0.30 & 7 & 0.30 \\
\hline Orbieu & 263 & 09_01_1996 & 55 & 45 & 1.17 & 0.65 & 0.53 & 7 & 0.48 \\
\hline Orbieu & 263 & 09_01_2004 & 57 & 33 & 1.08 & 0.87 & 0.28 & 6 & 0.74 \\
\hline Orbieu & 263 & 13_10_2005 & 46 & 113 & 0.94 & 0.73 & 0.88 & 10 & 0.47 \\
\hline Orbieu & 263 & 15_11_2005 & 55 & 149 & 0.97 & 0.85 & 2.65 & 5 & 0.71 \\
\hline Orbieu & 263 & 28_01_2006 & 55 & 229 & 1.11 & 0.93 & 1.27 & 4 & 0.46 \\
\hline Orbieu & 263 & 10_10_2010 & 42 & 211 & 1.06 & 0.88 & 0.97 & 8 & 0.37 \\
\hline Orbieu & 263 & 16_03_2011 & 51 & 172 & 1.05 & 0.84 & 0.68 & 6 & 0.72 \\
\hline Reart & 145 & 16_11_2003 & 62 & 128 & 0.89 & 0.51 & 0.44 & 3 & 0.31 \\
\hline Reart & 145 & 04_12_2003 & 66 & 100 & 0.91 & 0.87 & 0.25 & 8 & 0.24 \\
\hline Reart & 145 & 16_04_2004 & 61 & 60 & 1.01 & 0.94 & 0.90 & 8 & 0.21 \\
\hline Reart & 145 & 03_05_2004 & 66 & 54 & 1.06 & 0.85 & 0.23 & 3 & 0.22 \\
\hline Reart & 145 & 15_11_2005 & 61 & 111 & 0.90 & 0.77 & 0.71 & 5 & 0.18 \\
\hline Reart & 145 & 03_11_2011 & 57 & 62 & 0.93 & 0.83 & 0.08 & 3 & 0.17 \\
\hline Rosieres & 212 & 18_10_2006 & 55 & 202 & 1.14 & 0.53 & 1.07 & 6 & 0.43 \\
\hline Rosieres & 212 & 16_11_2006 & 58 & 146 & 1.03 & 0.71 & 1.12 & 4 & 0.51 \\
\hline Rosieres & 212 & 18_04_2008 & 52 & 142 & 1.04 & 0.78 & 0.75 & 4 & 0.74 \\
\hline Rosieres & 212 & 20_10_2008 & 57 & 206 & 0.87 & 0.79 & 1.34 & 4 & 0.37 \\
\hline Rosieres & 212 & 31_10_2008 & 65 & 283 & 1.10 & 0.62 & 1.44 & 6 & 0.66 \\
\hline Rosieres & 212 & 05_05_2010 & 53 & 102 & 1.02 & 0.74 & 0.72 & 5 & 0.57 \\
\hline Salz & 144 & 20_04_1981 & 50 & 71 & - & - & 0.56 & 7 & 0.55 \\
\hline Salz & 144 & 14_01_1982 & 50 & 98 & - & - & 1.63 & 5 & 0.89 \\
\hline Salz & 144 & 03_04_1988 & 50 & 55 & - & - & 1.03 & 4 & 0.87 \\
\hline Salz & 144 & 23_04_1988 & 50 & 66 & - & - & 0.49 & 4 & 0.60 \\
\hline Salz & 144 & 23_03_1991 & 50 & 124 & - & - & 1.10 & 7 & 0.58 \\
\hline Salz & 144 & 09_01_1996 & 50 & 44 & - & - & 0.74 & 4 & 0.72 \\
\hline Salz & 144 & 30_11_1996 & 50 & 64 & - & - & 0.69 & 6 & 0.47 \\
\hline Salz & 144 & 10_06_2000 & 57 & 113 & 1.04 & 0.99 & 1.40 & 5 & 0.73 \\
\hline Salz & 144 & 20_12_2000 & 50 & 141 & - & - & 1.42 & 8 & 0.45 \\
\hline Salz & 144 & 10_01_2004 & 64 & 49 & 0.97 & 0.96 & 0.46 & 5 & 0.29 \\
\hline Salz & 144 & 11_10_2010 & 47 & 136 & 1.05 & 0.91 & 2.19 & 7 & 0.59 \\
\hline Tech & 250 & 02_12_1991 & 50 & 396 & 1.02 & 0.89 & 1.56 & 6 & 0.68 \\
\hline Tech & 250 & 25_09_1992 & 50 & 213 & 1.13 & 0.97 & 2.51 & 3 & 0.20 \\
\hline Tech & 250 & 13_11_1999 & 50 & 294 & 0.95 & 0.87 & 1.15 & 7 & 0.18 \\
\hline Tech & 250 & 23_12_2000 & 50 & 226 & 1.04 & 0.98 & 0.79 & 8 & 0.25 \\
\hline Tech & 250 & 24_02_2003 & 54 & 70 & 1.07 & 0.99 & 0.57 & 8 & 0.30 \\
\hline
\end{tabular}


Table 1 (continued)

\begin{tabular}{|c|c|c|c|c|c|c|c|c|c|}
\hline Catchment & Area $\left(\mathrm{km}^{2}\right)$ & Event & $\begin{array}{l}\text { Initial soil } \\
\text { moisture (\%) }\end{array}$ & $\begin{array}{l}\text { Cumulated } \\
\text { rainfall }(\mathrm{mm})\end{array}$ & $\begin{array}{l}\text { Delta1 } \\
(-)\end{array}$ & $\begin{array}{l}\text { Delta2 } \\
(-)\end{array}$ & $\begin{array}{l}\text { Specific peak flow } \\
\text { discharge }\left(\mathrm{m}^{3} \mathrm{~s}^{-1} \mathrm{~km}^{2}\right)\end{array}$ & $\begin{array}{l}\text { Lag } \\
\text { time }(\mathrm{h})\end{array}$ & $\begin{array}{l}\text { Runoff } \\
\text { coefficient (-) }\end{array}$ \\
\hline Tech & 250 & 04_12_2003 & 55 & 30 & 0.96 & 0.96 & 0.62 & 8 & 0.30 \\
\hline Tech & 250 & 15_11_2005 & 60 & 99 & 0.85 & 0.80 & 0.63 & 7 & 0.24 \\
\hline Tech & 250 & 28_01_2006 & 49 & 128 & 1.08 & 0.71 & 1.08 & 6 & 0.79 \\
\hline Tech & 250 & 15_03_2011 & 47 & 281 & 1.04 & 0.83 & 2.24 & 8 & 0.64 \\
\hline Tet & 776 & 15_04_2004 & 55 & 125 & 0.86 & 0.64 & 0.58 & 5 & 0.35 \\
\hline Tet & 776 & 02_05_2004 & 60 & 113 & 1.02 & 0.86 & 0.51 & 7 & 0.38 \\
\hline Tet & 776 & 15_03_2011 & 53 & 87 & 0.82 & 0.98 & 1.13 & 10 & 0.22 \\
\hline Verdouble & 299 & 08_05_1991 & 50 & 56 & 1.11 & 0.95 & 0.41 & 8 & 0.39 \\
\hline Verdouble & 299 & 05_12_1996 & 71 & 65 & 0.94 & 0.85 & 2.04 & 9 & 0.86 \\
\hline Verdouble & 299 & 09_11_1999 & 55 & 179 & 0.95 & 0.73 & 3.00 & 10 & 0.80 \\
\hline Verdouble & 299 & 11_04_2002 & 69 & 169 & 1.02 & 0.76 & 0.95 & 4 & 0.76 \\
\hline Verdouble & 299 & 04_12_2003 & 66 & 133 & 1.09 & 0.89 & 0.70 & 9 & 0.89 \\
\hline Verdouble & 299 & 21_02_2004 & 63 & 50 & 0.98 & 1.00 & 0.43 & 10 & 0.52 \\
\hline Verdouble & 299 & 15_11_2005 & 70 & 215 & 0.90 & 0.82 & 3.30 & 6 & 0.82 \\
\hline Verdouble & 299 & 28_01_2006 & 64 & 249 & 1.01 & 0.99 & 1.96 & 5 & 0.99 \\
\hline Verdouble & 299 & 10_10_2010 & 52 & 262 & 1.01 & 0.88 & 1.47 & 12 & 0.88 \\
\hline Verdouble & 299 & 12_03_2011 & 59 & 217 & 1.01 & 0.82 & 1.23 & 7 & 0.82 \\
\hline Vogue & 619 & 18_10_2006 & 56 & 140 & 1.16 & 0.51 & 0.89 & 10 & 0.57 \\
\hline Vogue & 619 & 16_11_2006 & 61 & 186 & 1.01 & 0.73 & 1.13 & 7 & 0.54 \\
\hline Vogue & 619 & 18_04_2008 & 55 & 120 & 1.02 & 0.76 & 0.48 & 6 & 0.59 \\
\hline Vogue & 619 & 20_10_2008 & 62 & 195 & 0.93 & 0.72 & 1.45 & 9 & 0.46 \\
\hline Vogue & 619 & 31_10_2008 & 70 & 211 & 1.16 & 0.52 & 1.62 & 11 & 0.94 \\
\hline Vogue & 619 & 05_05_2010 & 55 & 98 & 1.01 & 0.70 & 0.76 & 11 & 0.45 \\
\hline Vogue & 619 & 03_11_2011 & 54 & 369 & 1.12 & 0.67 & 1.34 & 8 & 0.77 \\
\hline Réal Martin & 283 & 09_12_2008 & 50 & 197 & 1.04 & 0.88 & 0.60 & 9 & 0.41 \\
\hline Réal Martin & 283 & 25_01_2009 & 50 & 42 & 1.03 & 0.95 & 0.29 & 7 & 0.66 \\
\hline Réal Martin & 283 & 14_06_2010 & 50 & 140 & 1.04 & 0.92 & 0.48 & 6 & 0.40 \\
\hline Réal Martin & 283 & 21_12_2010 & 50 & 113 & 1.06 & 0.84 & 0.31 & 6 & 0.31 \\
\hline Réal Martin & 283 & 14_03_2011 & 50 & 131 & 1.07 & 0.95 & 0.26 & 8 & 0.43 \\
\hline Nartuby & 196 & 02_12_2006 & 50 & 93 & 1.00 & 0.85 & 0.20 & 7 & 0.11 \\
\hline Nartuby & 196 & 21_12_2009 & 50 & 37 & 1.05 & 0.84 & 0.09 & 5 & 0.23 \\
\hline Nartuby & 196 & 21_12_2010 & 50 & 96 & 0.98 & 0.88 & 0.20 & 6 & 0.29 \\
\hline Nartuby & 196 & 14_03_2011 & 50 & 45 & 1.05 & 0.82 & 0.13 & 6 & 0.49 \\
\hline Nartuby & 196 & 03_11_2011 & 50 & 240 & 1.02 & 0.86 & 0.54 & 6 & 0.27 \\
\hline Gapeau & 535 & 09_12_2008 & 50 & 164 & 0.99 & 0.83 & 0.40 & 8 & 0.44 \\
\hline Gapeau & 535 & 25_01_2009 & 50 & 35 & 0.98 & 0.89 & 0.21 & 10 & 0.66 \\
\hline Gapeau & 535 & 21_12_2009 & 50 & 111 & 0.99 & 0.92 & 0.33 & 5 & 0.45 \\
\hline Gapeau & 535 & 14_06_2010 & 50 & 116 & 1.00 & 0.81 & 0.30 & 9 & 0.34 \\
\hline Gapeau & 535 & 21_12_2010 & 50 & 108 & 1.01 & 0.83 & 0.38 & 7 & 0.39 \\
\hline Gapeau & 535 & 03_11_2011 & 50 & 291 & 1.07 & 0.77 & 0.60 & 7 & 0.43 \\
\hline Aille & 227 & 02_12_2006 & 50 & 115 & 1.00 & 0.83 & 0.20 & 7 & 0.24 \\
\hline Aille & 227 & 03_11_2008 & 50 & 102 & 0.93 & 0.75 & 1.04 & 4 & 0.53 \\
\hline Aille & 227 & 09_12_2008 & 50 & 234 & 0.99 & 0.84 & 0.91 & 5 & 0.66 \\
\hline Aille & 227 & 21_12_2009 & 50 & 104 & 1.01 & 0.88 & 0.72 & 3 & 0.65 \\
\hline Aille & 227 & 14_06_2010 & 50 & 196 & 0.94 & 0.84 & 2.30 & 6 & 0.65 \\
\hline Aille & 227 & 21_12_2010 & 50 & 134 & 1.01 & 0.78 & 0.70 & 4 & 0.70 \\
\hline Aille & 227 & 04_06_2011 & 50 & 32 & 0.81 & 0.64 & 0.20 & 3 & 0.12 \\
\hline Aille & 227 & 03_11_2011 & 50 & 333 & 1.00 & 0.79 & 1.30 & 6 & 0.82 \\
\hline
\end{tabular}

- The attempt of regionalizing the parameters of a flash-flood dedicated model: to our knowledge, this is the first study of regionalization for flash flood events.

- MARINE parsimonious formulation and parameters physical meaning (cf. Section 2).

- The large dataset of catchments and flash floods gathered, including radar rainfalls at 5 min time step, despite the difficulties involved in monitoring flash floods (cf. Section 2).

- The possibility of investigating the link between catchment's flood behaviours with soil and bedrock structure, thanks to the availability of spatially distributed pedological and geological data for the French catchments of interest.

This study is organized as follows. Section 2 presents the modelling framework, the study zone and the flash flood events. Physiographic descriptors of catchment are presented along with MARINE model and the calibrated parameter sets, the cost functions used to assess model performance and the regionalization methodologies. Section 3 discusses the results from calibration/validation to regionalization. Documentation about calibration/validation efficiencies is provided for the whole flash flood events dataset. In the light of those performances, regionalization results are analysed with global statistics on model efficiency for the whole dataset, for each catchment and for each event.

\section{Modelling framework}

\subsection{Study zone and selected catchment descriptors}

This study is based on data from 16 small to medium-sized catchments with areas ranging from 144 to $786 \mathrm{~km}^{2}$ (Fig. 1) and contrasting physiographic properties (Table 3 ). These 16 gauged catchments are located in the French Mediterranean region (Table 3), represent a large sample of landscapes from Pyrenean, Mediterranean, Cévennes-Vivarais and Provence regions. The 
Table 2

Some regionalization studies and three broad categories of regionalization methods.

\begin{tabular}{|c|c|c|c|}
\hline Method & Main idea & References & Description and main results \\
\hline $\begin{array}{l}\text { Regression } \\
\text { based }\end{array}$ & $\begin{array}{l}\text { Interpolation of model parameters. Model parameters related to } \\
\text { catchment characteristics in a statistical manner }\end{array}$ & $\begin{array}{l}\text { Abdulla and } \\
\text { Lettenmaier } \\
\text { (1997) } \\
\text { Kokkonen } \\
\text { et al. (2003) } \\
\\
\text { Hundecha and } \\
\text { Bárdossy } \\
\text { (2004) } \\
\text { Merz and } \\
\text { Blöschl (2004) } \\
\text { Oudin et al. } \\
\text { (2008) } \\
\text { Viviroli et al. } \\
\text { (2009) }\end{array}$ & $\begin{array}{l}34 \text { catchments of the Arkansas-Red River basin (USA), } 3 \\
\text { parameters of VIC-2L } \\
13 \text { catchments of the North Carolina-Coweeta River basin } \\
\text { (USA), } 6 \text { parameters of the IHACRES model. "If a gauged } \\
\text { catchment resembles the ungauged one in terms of } \\
\text { hydrological behaviour, (...) worthwhile to adopt entire } \\
\text { calibrated parameter sets" } \\
95 \text { catchments in the Rhine basin (Germany), } 12 \text { parameters of } \\
\text { the HBV-IWS model } \\
300 \text { Austrian catchments, } 11 \text { parameters of the HBV model } \\
913 \text { French catchments, } 4 \text { parameters of GR4J model or } 6 \\
\text { parameters of TOPMODEL } \\
\text { Built on } 140 \text { catchments in Switzerland and tested on } 49,12 \\
\text { parameters of PREVAH model }\end{array}$ \\
\hline $\begin{array}{r}\text { Geographical } \\
\text { proximity }\end{array}$ & $\begin{array}{l}\text { Geographically close catchments behave similarly; homogeneity of } \\
\text { climate and physiographic properties }\end{array}$ & $\begin{array}{l}\text { Vandewiele } \\
\text { and Elias } \\
\text { (1995) } \\
\text { Merz and } \\
\text { Blöschl (2004) } \\
\text { Parajka et al. } \\
\text { (2005) } \\
\text { Oudin et al. } \\
\text { (2008) } \\
\text { Viviroli et al. } \\
\text { (2009) } \\
\text { Patil and } \\
\text { Stieglitz } \\
\text { (2012) }\end{array}$ & $\begin{array}{l}75 \text { Belgian catchments, } 5 \text { parameters conceptual model, } \\
\text { Krigging performs better than proximity } \\
300 \text { Austrian catchments, } 11 \text { parameters of the HBV model. Best } \\
\text { regionalization method: average of upstream and downstream } \\
\text { neighbours or krigging } \\
320 \text { Austrian catchments, } 11 \text { parameters of the HBV model } \\
913 \text { French catchments, } 4 \text { parameters of GR4J model or } 6 \\
\text { parameters of TOPMODEL. Proximity provides best results } \\
\text { with a rather dense gaging network } \\
\text { Built on } 140 \text { catchments in Switzerland and tested on } 49,12 \\
\text { parameters of PREVAH model } \\
756 \text { US catchments, regionalization of a multiple drainage-area } \\
\text { ration method based on donor-receptor proximity. Detection of } \\
\text { hydrologic regions, low predictability for drier regions }\end{array}$ \\
\hline $\begin{array}{l}\text { Catchment } \\
\text { similarity }\end{array}$ & $\begin{array}{l}\text { Hydrological behaviour can be explained by catchment } \\
\text { descriptors, and transferred to ungauged catchments similar in } \\
\text { terms of those descriptors }\end{array}$ & $\begin{array}{l}\text { McIntyre et al. } \\
\text { (2005) } \\
\text { Parajka et al. } \\
\text { (2005) } \\
\text { Oudin et al. } \\
(2008)\end{array}$ & $\begin{array}{l}127 \text { UK catchments and the } 5 \text { parameters PDM model. Physical } \\
\text { similarity outperforms regression methods } \\
320 \text { Austrian catchments, } 11 \text { parameters of the HBV model. } \\
\text { Slightly better efficiency for similarity approach compared to } \\
\text { krigging } \\
913 \text { French catchments, } 4 \text { parameters of GR4J model or } 6 \\
\text { parameters of TOPMODEL. "Lack of a key physical } \\
\text { descriptor..."; they suggest to combine the three kind of } \\
\text { approaches } \\
\text { Built on } 140 \text { catchments in Switzerland and tested on } 49,12 \\
\text { parameters of PREVAH model. Best results when combining } \\
\text { the three kinds of approaches } \\
41 \text { German catchments, regionalization of the HBV model based } \\
\text { on similarity measured with self-organizing maps (neural } \\
\text { networks). Mean Nash on the order of } \mathbf{0 . 5 5} \text { comparable to } \\
\text { lots of other regionalization studies }\end{array}$ \\
\hline
\end{tabular}

proximity with the sea and the steep surrounding topography can foster heavy precipitation events. The highest flooding risk is in autumn with wet soils and maximum rainfall rates. Summers are hot and dry; however summer storms also represent a non-negligible flooding risk. For this study, radar rainfall records (Fig. 1, orange $^{1}$ dots) readjusted on the raingauge network are available. Three types of data are used to derive input maps for MARINE model (Fig. 2):

- A DEM data file of the study site with a grid scale of $25 \mathrm{~m}$ was available from the National Geographic Institute (BD TOPO ${ }^{\circledR}$ (C) Institut Géographique National - Paris - 2008. ( ) (SCHAPI, Service Central d'Hydrométéorologie et d'Appui à la Prévision des Inondations)). For these catchments with a highly marked topography, the mean elevation ratio is $0.035 \mathrm{~mm}^{-1}$ (Height difference/Longest flow path).

\footnotetext{
${ }^{1}$ For interpretation of color in Fig. 1, the reader is referred to the web version of this article.
}

- Soil thicknesses and textures were available from soil surveys BDSol-LR (Robbez-Masson et al., 2002) (IGCS - BDSol-LR version $n^{\circ}$ 2006, INRA - Montpellier SupAgro) and BDSolArdèche. For catchments 13-16 in Provence, no detailed soil survey was available and the same soil thickness and textures as SIM model (Habets et al., 2008) have been used.

- Soil saturated hydraulic conductivities, saturated water contents and soil suctions are determined with Rawls and Brakensiek (1985) pedotransfer functions as proposed by Manus et al. (2009).

A vegetation and land-use map (Corine Land Cover provided by the Service de l'Observation et des Statistiques (SOeS) of the French Ministry of Environment, www.ifen.fr) is used to derive distributed surface roughness. Most catchments' surfaces are forested with Mediterranean or Alpine vegetation, or occupied by vineyard.

Gathering appropriate attributes to characterize catchments properties and unicity is an important step for regionalization purpose. For example the UK Flood Estimation Handbook (IH, 1999) 


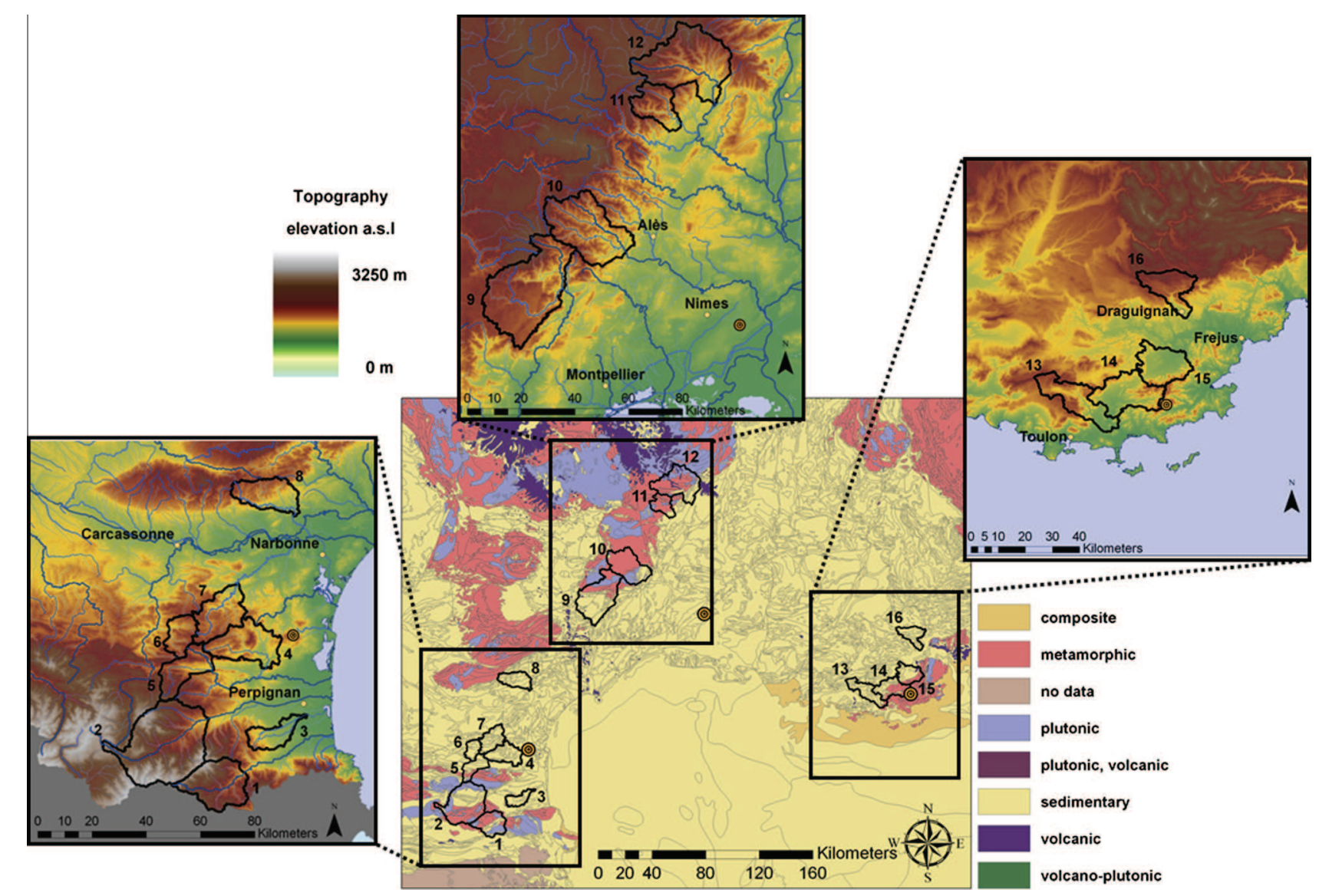

Fig. 1. (Center) Simplified bedrock composition of the French Mediterranean region (source: (Bd Million-Géol, BRGM)) and (periphery) topography. (Black contours) 16 unregulated catchments of interest. (West to the east) Opoul, Nîmes and Collobrières meteorological radars from Météo France network (orange dots with black concentric circles).

recommends the use of 3 catchment descriptors for model parameter transfer, Samaniego and Bardossy (2005) used 7 attributes for their study.

Simplified bedrock composition (Fig. 1) is derived from lithological data (source: (Bd Million-Géol, BRGM)). Among the variety of pedologic data that can be found in soil surveys, maps are derived for some hydrodynamic parameters of the soil represented in MARINE model (cf. § 2.2) and several catchment averaged descriptors can therefore be calculated. Simple descriptors of soil and bedrock are presented in Table 3.

To sum up, a total of 13 physiographic attributes are considered for this regionalization study. It constitutes an important number of attributes regarding other regionalization studies (IH, 1999; Samaniego and Bardossy, 2005).

\subsection{MARINE flash flood physics-based model and calibrated parameter sets}

\subsubsection{Model basics}

For flood event modelling, and especially flash floods, the modeller is facing the challenge of choosing a rainfall runoff model, then calibrating a parameter set able to simulate flood events and related hydrograph shape accurately, and last but not least evaluating performance on each event with a cost function.

In this study the distributed model MARINE for flash flood forecasting (Roux et al., 2011) with subsurface transfer module is used. The predominant factor determining the formation of runoff is represented by the topography: slope and downhill directions. Both infiltration excess and saturation excess are represented within MARINE which is structured into three main modules (Fig. 2). The first module allows separating the precipitation into surface runoff and infiltration using the Green and Ampt model; the second module represents subsurface downhill flow with an approximation of the Darcy's law and the third one the overland flow (over hillslopes and in the drainage network): the transfer function component allows routing the rainfall excess to the catchment outlet using the kinematic wave approximation. The spatial discretization of the catchment is performed using the Digital Elevation Model grid resolution, a regular grid of $200 \mathrm{~m}$ squared cells. Evapotranspiration is not represented since the model purpose was to simulate individual flood events during which such process is negligible. For a complete description of the MARINE model the reader can refer to Roux et al. (2011).

In order to avoid a model over-parameterization, spatial patterns of several parameters are derived from soil surveys and a unique correction coefficient is then applied to each parameter map. This approach has been chosen for three parameters, namely the distributed saturated hydraulic conductivity $K$, the lateral transmissivity $T_{0}$ and soil thickness $Z$. The calibration procedure consists in estimating: three coefficients of correction for spatialized data; one for the saturated hydraulic conductivities, named $C_{K}$, another one $C_{\mathrm{KSS}}$ for the lateral subsurface flow transmissivities $\left(T_{0}\right)$, and the last one for the soil thicknesses, named $C_{Z}$, the Strickler roughness coefficient of the main channel $K_{D 1}$ and the Strickler roughness coefficient of the overbanks of the drainage network $K_{D 2}$ (Garambois et al., 2013; Roux et al., 2011). Concerning the transmissivity $K_{\mathrm{ss}}$, the spatial variability is taken from the hydraulic conductivity map. 


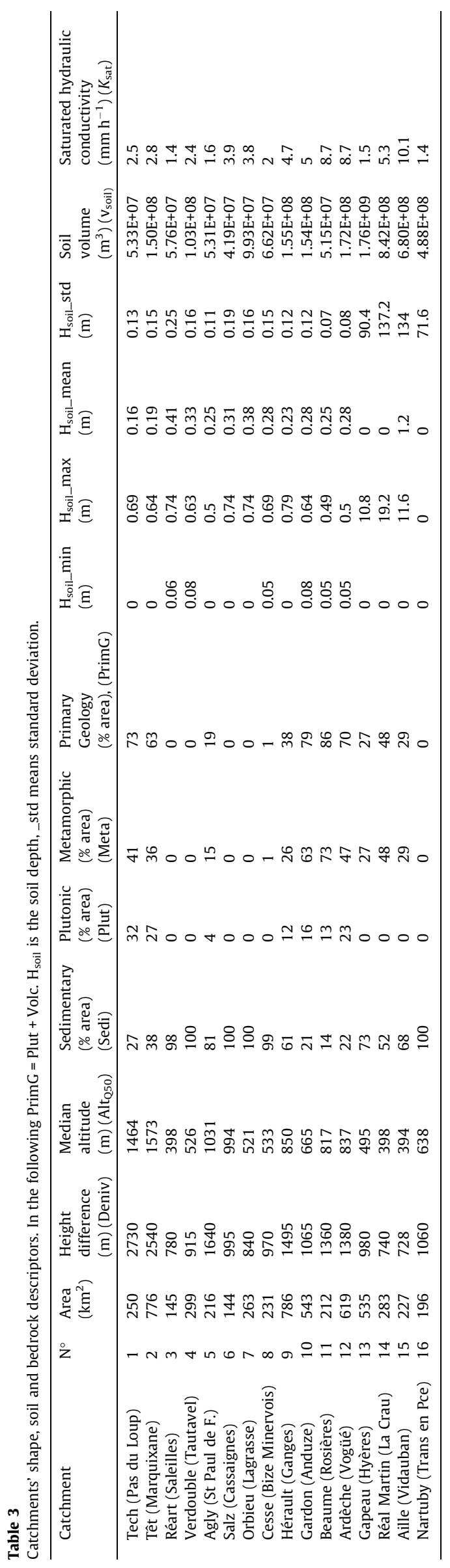

A continuous soil moisture model (SIM) (Habets et al., 2008) is used for the initialization of the soil moisture at the beginning of an event within MARINE model. The root zone soil moisture from $\mathrm{SIM}$ is used $\left(\mathrm{Hu}_{2}\right.$ index cf. (Marchandise and Viel, 2009)). $\mathrm{Hu}_{2}$ index is calculated as follows: $\mathrm{Hu}_{2}=\mathrm{wg}_{2} / \mathrm{wg}_{\text {sat2 } 2}$ where $\mathrm{wg}_{2}$ is the volumetric water content of the root zone and $\mathrm{wg}_{\text {sat2 }}$ is the saturated volumetric water content of the root zone. $\mathrm{Hu}_{2}$ index (\%) at the beginning of each event is applied to each cell within catchment discretization. It has been shown that initial soil moisture condition has to be set for each event for a robust calibration (Roux et al., 2011). Indeed, results show that there is a non-negligible sensitivity of the model response to the initial soil moisture. Following this study, it has been chosen to use $\mathrm{Hu}_{2}$ index, when available, as soil moisture initialization for the MARINE.

MARINE model is the result of a mechanistic approach representing flow components that are considered predominant in Mediterranean flash flood genesis. Several sensitivity analysis and calibration/validation (cal/val) of the model have been performed for catchments of the French Mediterranean region with areas ranging from about $100 \mathrm{~km}^{2}$ to $700 \mathrm{~km}^{2}$ (Garambois et al., 2013, 2015; Roux et al., 2011). The results of these studies show that soil depth and lateral water transfer through the subsurface zone have a significant impact on soil saturation dynamics and flood hydrograph. Drainage network reveals to be important also.

\subsubsection{Calibrated parameter sets}

The choice of a cost function is of prior importance to assess rainfall runoff modelling performances. Timing and maximum discharge of peak flow are important features to compare the shape of flash floods hydrographs'. They will be taken into account thanks to the $L_{\mathrm{NP}}$ cost function (Eq. (1)) (Roux et al., 2011):

$L_{\mathrm{NP}}=\frac{1}{3} \mathrm{Nash}+\frac{1}{3} \cdot\left(1-d Q_{p}\right)+\frac{1}{3} \cdot\left(1-d T_{p}\right)$

with

Nash $=\cdot 1-\frac{\sum_{i=1}^{N_{\mathrm{obs}}}\left(Q_{s}^{t}-Q_{o}^{t}\right)^{2}}{\sum_{i=1}^{N_{\mathrm{obs}}}\left(Q_{o}^{t}-\overline{Q_{0}}\right)^{2}} ; \quad d Q_{p}=\frac{\left|Q_{s}^{p}-Q_{o}^{p}\right|}{Q_{o}^{p}} ;$

$d T_{p}=\frac{\left|T_{s}^{p}-T_{o}^{p}\right|}{T_{o}^{c}}$

where $N_{\text {obs }}$ is the number of observation data, $Q_{S}$ and $Q_{0}$ are respectively the simulated and the observed runoff, $Q_{s}^{P}$ and $Q_{o}^{P}$ are respectively the simulated and observed peak runoff, $T_{P}^{S}$ and $T_{P}^{o}$ are respectively the simulated and observed time to peak, $T_{o}^{C}$ is the time of concentration of the catchment determined by averaging Bransby formula $\left(T_{o}^{c}=\frac{21.3 L}{A^{0.1} S^{0.2}}, L\right.$ is the channel length $(\mathrm{m}), A$ is the catchment area $\left(\mathrm{m}^{2}\right)$ and $S$ the linear profile slope $\left.(\mathrm{m} / \mathrm{m})\right)$. Compared to the Nash cost function (Eq. (2)), the $L_{\mathrm{NP}}$ cost function grants more importance to peak flow value and timing, which is particularly appropriate for the MARINE model, which focuses more on flash flood peak flow modelling than on baseflow or recession. This multi criteria cost function is used to assess model performances for each flood event in order to avoid classical significance problems of Nash criterion used alone for flood events (Moussa, 2010).

Our approach to test MARINE model potential for flash flood regionalization is to calibrate MARINE model parameters for each gauged catchment (Table 4). For 16 catchments with sufficient flash flood records for calibration and validation, parameters sets were calibrated on several events per catchment ((Nash, $\left.L_{\mathrm{NP}}\right) \sim(0.8 ; 0.8)$, cf. Table 6). Extreme events, such as September 2002 in the Cévennes, are not used for calibration. The full procedure of event selection for calibration can be found in Garambois et al. (2015). 


\section{Distributed input data}

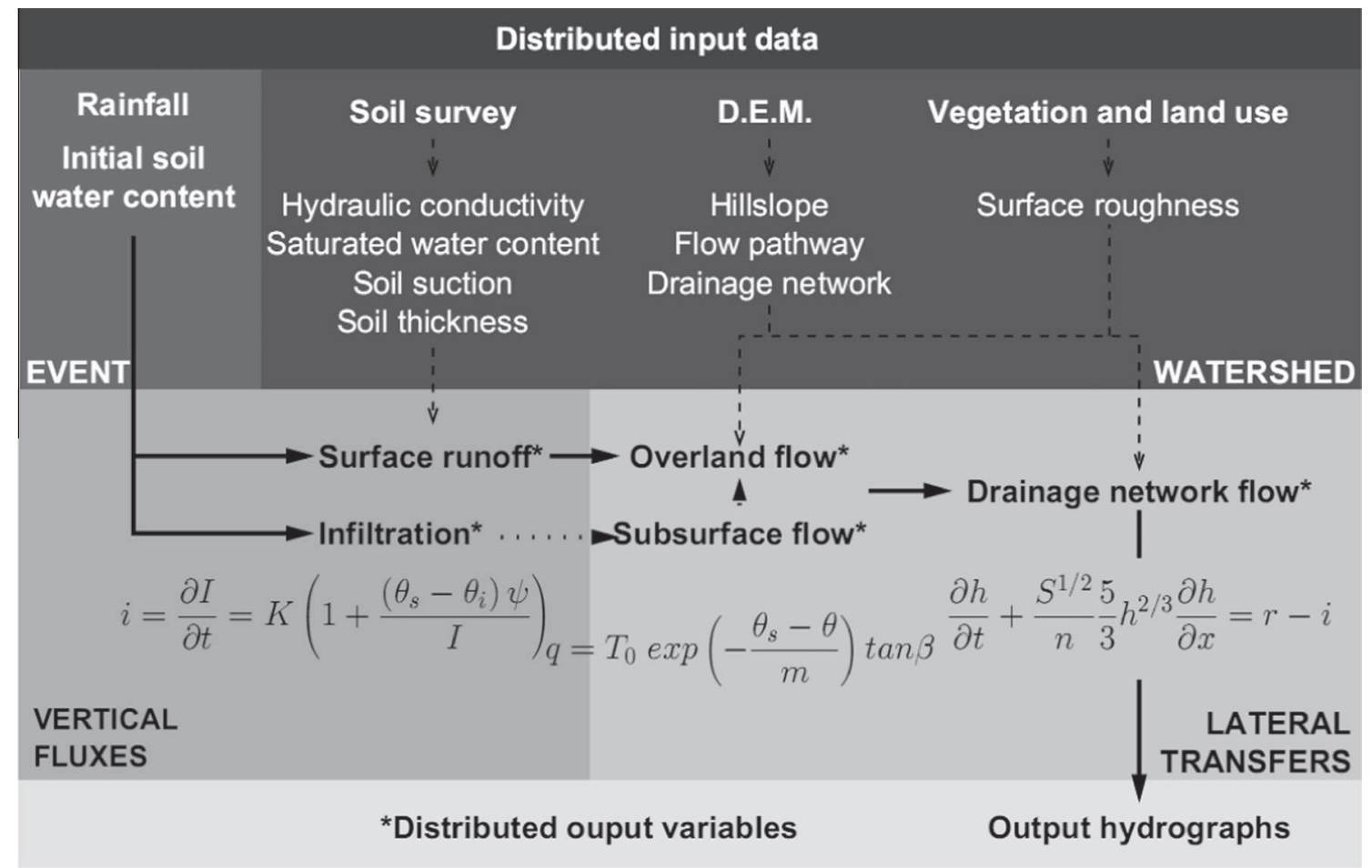

Fig. 2. MARINE model structure, parameters and variables. Infiltration rate $i\left(\mathrm{~m} \mathrm{~s}^{-1}\right)$, cumulative infiltration $I$ (mm), saturated hydraulic conductivity $K$ ( $\left.\mathrm{m} \mathrm{s}^{-1}\right)$, soil suction at wetting front $\psi(\mathrm{m})$, saturated and initial water contents are respectively $\theta_{s}$ and $\theta_{i}\left(\mathrm{~m}^{3} \mathrm{~m}^{-3}\right)$. Local transmissivity of fully saturated soil $T_{0}\left(\mathrm{~m}^{2} \mathrm{~s}^{-1}\right)$, saturated and local water contents are $\theta_{\mathrm{s}}$ and $\theta\left(\mathrm{m}^{3} \mathrm{~m}^{-3}\right)$, transmissivity decay parameter is $\mathrm{m}(-)$, local slope angle $\beta(\mathrm{rad})$. Water depth $h(\mathrm{~m})$, time $t(\mathrm{~s})$, overland flow velocity $u\left(\mathrm{~m} \mathrm{~s}{ }^{-1}\right)$, space variable $x(\mathrm{~m})$, rainfall rate $r\left(\mathrm{~m} \mathrm{~s}^{-1}\right)$, infiltration rate $i\left(\mathrm{~m} \mathrm{~s}^{-1}\right)$, bed slope $S\left(\mathrm{~m} \mathrm{~m}^{-1}\right)$, Manning roughness coefficient $\mathrm{n}\left(\mathrm{m}^{-1 / 3} \mathrm{~s}\right)$.

Table 4

Calibrated parameter sets for gauged catchments.

\begin{tabular}{llllll}
\hline Catch. & $C_{Z}(-)$ & $C_{K}(-)$ & $C_{\mathrm{KSS}}(-)$ & $K_{D 1}\left(\mathrm{~m}^{1 / 3} / \mathrm{s}\right)$ & $K_{D 2}\left(\mathrm{~m}^{1 / 3} / \mathrm{s}\right)$ \\
\hline Tech & 4.3 & 11 & 1515 & 5 & 3.2 \\
Têt & 6.1 & 19.8 & 10,000 & 11.8 & 3.4 \\
Réart & 4.29 & 15 & 1242 & 5.7 & 30 \\
Verdouble & 1.3 & 15 & 4486 & 5 & 4 \\
Agly & 1.6 & 20 & 4304 & 7.5 & 2.2 \\
Salz & 1 & 20 & 5595 & 5 & 5 \\
Orbieu & 1.3 & 15 & 10,000 & 9.1 & 2 \\
Cesse & 1.26 & 7.7 & 10,000 & 5 & 6.3 \\
Hérault & 3.6 & 17.8 & 4764 & 8.2 & 5 \\
Gardon & 4.6 & 10.3 & 4540 & 11.7 & 9.7 \\
Beaume & 5.3 & 7.4 & 3712 & 21.4 & 14.7 \\
Ardèche & 3.4 & 2.1 & 4891 & 10 & 19.1 \\
Gapeau & 1.2 & 4.76 & 1200 & 14 & 20.8 \\
Réal Martin & 1.28 & 3 & 415 & 19.7 & 5 \\
Aille & 0.4 & 4 & 715 & 31.2 & 7 \\
Nartuby & 1.12 & 10.5 & 4525 & 22 & 5 \\
\hline
\end{tabular}

Parameter sets are then tested on several recent strong events ((Nash, $\left.L_{\mathrm{NP}}\right) \sim(0.7,0.7)$, (Fig. 3$)$ ) since one of the objectives is flash flood forecasting. The comparison between observed and simulated maximum specific discharges (Fig. 3) highlights good performances of MARINE model even for specific discharges up to $6.3 \mathrm{~m}^{3} \mathrm{~s}^{-1} \mathrm{~km}^{-2}$; keeping in mind that gauging uncertainty can be close to $\pm 20 \%$ or even $30 \%$ for such high flows (see e.g. (Delrieu et al., 2005)).

MARINE model parameters present few interactions during peak flow simulations as shown with temporal variance analysis on 6 Mediterranean catchments (Garambois et al., 2013). This probably stems from model parsimony and physical formulation. Reducing parameter interactions and equifinality problems is important especially for flood forecasting at gauged and ungauged locations.

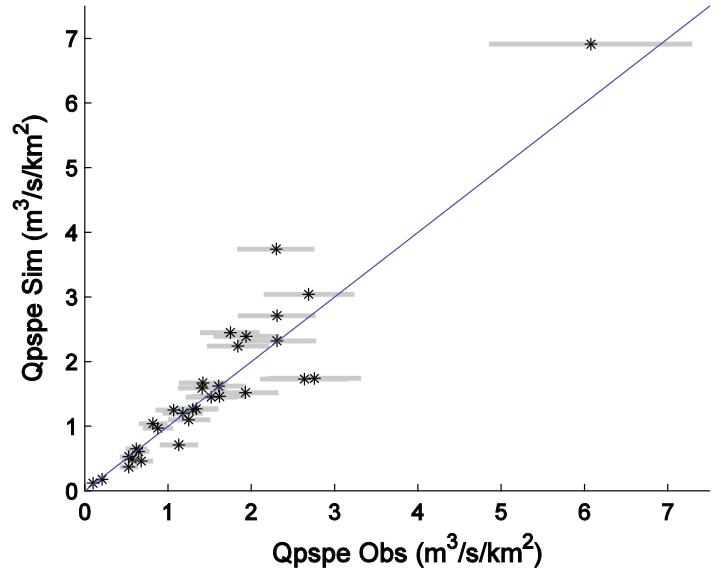

Fig. 3. (Black stars) Maximum simulated specific discharges versus observed for validation events which are recent strong events. (Grey bars) Representation of an indicative $\pm 20 \%$ gauging error for peak discharge observation (see e.g. (Delrieu et al., 2005)).

\subsection{Regionalization methodology}

As stated before, 5 tuneable parameters of MARINE model are calibrated for catchments with sufficient flood records (Section 2.2), but the application of MARINE model in the case of ungauged catchments requires a regionalization method. MARINE model parameters are estimated using two approaches namely the nearest neighbours and a similarity approach. The issue of selecting information that is best transferred from donor catchment(s) to the ungauged one is addressed. Proximity measure and/or catchment physiographic descriptors are used to derive a similarity measure between gauged and ungauged catchments. 


\subsubsection{Single correlations}

As a first step, correlations between calibrated model parameters and catchment descriptors have been tested. The single regressions are established for all the 16 gauged catchments. The correlation coefficients of the regressions equations between the model parameter values and 13 descriptors are usually lower than 0.5 (Table 5). Other regionalization studies find also correlation coefficients usually lower than 0.5 for continuous rainfall runoff models (Merz et al., 2006; Oudin et al., 2008). The highest correlations are found for $C_{Z}$, the multiplicative constant of the soil depths (Table 5), which is also the most sensitive parameter of the model (Garambois et al., 2013, 2015). Indeed, the soil depth multiplicative constant explains $80 \%$ of model output variance when most hydrographs are peaking (Garambois et al., 2013). Catchment soil volume from pedologic data has to be adjusted with $C_{Z}$ which is the most influent parameter of MARINE model on average. Within our modelling framework $C_{Z}$ values larger than 1 indicates that catchment storage capacity needs to be increased for flash flood modelling purpose. For catchments with comparable areas, soil volumes and bedrocks such as the Cesse, the Verdouble or the Agly, $C_{Z}$ is close to one which is three times lower than those necessary to correctly reproduce rainfall to runoff conservation on the Hérault and Ardèche. The $C_{Z}$ on the Tech, Têt and Gardon are even larger. Moreover for initial soil moisture of approximately $50 \%$, the soil volume is nearly entirely solicited as shown by maximum soil saturation condition in the range of $80-90 \%$ at the end of an event. A significant volume of flood triggering rainfall might percolate to deeper fractured layers as proposed by other authors (Castaings et al., 2009; Garambois et al., 2015; Roux et al., 2011). $C_{Z}$ could then be related to catchments' bedrock descriptors that are not taken into account in the model. This may be due to the fact that the soil depth from soil surveys used in modelling only takes soil horizons A (surface soil) and B (subsoil) into account. Horizons C (parent rock) and $\mathrm{R}$ (bedrock) are not taken into account even though they may be hydrologically active (Garambois et al., 2015). The higher $C_{Z}$ values are for catchments areas developing on primary era bedrock such as the Tech, the Têt, the Gardon, the Beaume or the Ardèche (Table 4 and Fig. 1). This is in agreement with recent results, obtained for different time scales through streamflow recession and cumulated rainfall analysis: Vannier et al. (2013) highlight relations between geology and drainage-storage capacity for 23 catchment areas $\left(0.2-291 \mathrm{~km}^{2}\right)$ located in the CévennesVivarais region.

\subsubsection{Distance measure}

For both geographical proximity and similarity approaches a measure of distance is required to evaluate the proximity of an ungauged catchment from potential donors. A common method consists in calculating the Euclidian distance between two catchments in the n-dimensional space of catchment attributes (Viviroli et al., 2009). We use attributes normalized by their maximum value because of their different variation ranges (Table 3 ) and the Euclidian distance for two catchments $i$ and $j$ is written as:

$D_{w}(i, j)=\sqrt{\sum_{k=1}^{n} w_{k}\left[\operatorname{attrib}_{k}^{*}(i)-\operatorname{attrib}_{k}^{*}(j)\right]^{2}}$ where attrib* refers to the $n$ normalized attributes, $w_{k}$ are userspecified weights than can be assigned for attributes to take into account their varying importance. In the following, attributes will be considered of equal importance and $D_{w}$ will be minimized in order to find the most similar catchment(s) given an ungauged one.

\subsubsection{Assessment of regionalization tests}

In order to assess the relative performances of the different methods for discharge estimation at ungauged location, the jack-knife technique was employed to compute and consequently evaluate the regionalization results. Catchments are successively considered as gauged and ungauged and parameters are retrieved from the other calibrated catchments. In the following, each catchment is treated as ungauged in turn. The combinations of parameters sets are calculated from gauged catchments using the proposed regionalization methods. The 16 catchments of interest representing a total of 117 events will be used in the following for regionalization trials (Garambois, 2012). For these catchments hydrographs simulated following a regionalization method can be compared to observed flood hydrographs. The efficiency of the methods are evaluated with $L_{\mathrm{NP}}$ criterion (cf. §2.2), Nash, $d Q_{p}$ and $d T_{p}$.

\section{Results and discussion}

\subsection{Model performance and calibration uncertainty}

The events selected are the strongest flood responses recorded during the period 1980-2011 for the catchments of interest. Specific peak flow discharges are superior to $0.2 \mathrm{~m}^{3} \mathrm{~s}^{-1} \mathrm{~km}^{2}$ for the selected catchments (cf. Table 1 in section 0 . Appendix A) As a preliminary, MARINE model was run for the whole flash flood events data set with the calibrated parameter sets (Table 6). For several catchments, floods of the 80's and 90's with rainfall fields derived from interpolated raingauges were considered. Indeed as far as possible we aim to evaluate predictive power of both MARINE model and regionalization methods on the largest dataset. Regionalization results will be presented hereafter for the 117 flood events with MARINE performances evaluated in (Table 6) and ranging from $\left(\mathrm{Nash} ; L_{\mathrm{NP}}\right)=(0.2 ; 0.26)$ to $(0.86 ; 0.88)$. For all catchments floods the mean values of (Nash; $\left.L_{\mathrm{NP}}\right)$ are $(0.54 ; 0.56)$ and more than 60 events are simulated with $L_{N P}>0.7$ i.e. approximately 4 events on average for each catchment.

Fig. 4 shows event cal/val performances for each catchment. The lowest efficiency is for the Nartuby which catchment area is mostly karstic, the Cesse catchment area is also karstic but performances are slightly better. 17 flood events out of 117 present $L_{\mathrm{NP}}$ coefficients close to 0 when testing calibrated parameter sets, with 8 of them for the Cesse and the Nartuby. However it appears interesting and more realistic to consider events with contrasted performances for the regionalization process and more generally to test the predictive abilities of an event flash-flood model.

The spreading of model performances can be important for some catchments like the Verdouble or Agly which are neighbours located in the Corbières Mountains or the Tech which is a steep catchment of the Pyrenean foothills. This can be attributable to

Table 5

Gauged catchments' simple correlations (Pearson's $R^{2}$ ) between calibrated parameter sets (on 61 events) from (Table 4) and catchment physical descriptors (Table 3).

\begin{tabular}{|c|c|c|c|c|c|c|c|c|c|c|c|c|c|}
\hline & Area & Deniv & Alt $_{50}$ & Sedi & Plut & Meta & PrimG $=$ Meta + Plut & Hsoil_min & Hsoil_max & Hsoil_mean & Hsoil_std & Vsoil & $K_{\text {sat }}$ \\
\hline$C_{Z}$ & 0.21 & 0.39 & 0.32 & 0.48 & 0.61 & 0.34 & 0.50 & 0.17 & 0.09 & 0.42 & 0.00 & 0.04 & 0.01 \\
\hline$C_{K}$ & 0.00 & 0.11 & 0.23 & 0.13 & 0.00 & 0.21 & 0.11 & 0.34 & 0.02 & 0.20 & 0.32 & 0.23 & 0.26 \\
\hline$C_{\mathrm{KSS}}$ & 0.05 & 0.03 & 0.08 & 0.04 & 0.01 & 0.09 & 0.03 & 0.23 & 0.00 & 0.18 & 0.03 & 0.09 & 0.04 \\
\hline$K_{D 1}$ & 0.01 & 0.07 & 0.10 & 0.05 & 0.03 & 0.14 & 0.05 & 0.52 & 0.00 & 0.28 & 0.28 & 0.10 & 0.34 \\
\hline$K_{D 2}$ & 0.00 & 0.08 & 0.12 & 0.01 & 0.00 & 0.02 & 0.01 & 0.00 & 0.01 & 0.08 & 0.04 & 0.08 & 0.01 \\
\hline
\end{tabular}


Table 6

Performance of MARINE model over the catchments and flood sets. The 16 catchments of interest represent a total of 117 flash floods. Number of calibration events in the first column between parentheses.

\begin{tabular}{|c|c|c|c|c|c|c|}
\hline & $\begin{array}{l}\text { Multiple events } \\
\text { calibration } \\
\text { (Nash) }\end{array}$ & $\begin{array}{l}\text { Validation Nash } \\
\text { (recent strong } \\
\text { events monitored } \\
\text { with radar) }\end{array}$ & $\begin{array}{l}\text { Validation } L_{\mathrm{NP}} \\
\text { (recent strong } \\
\text { events monitored } \\
\text { with radar) }\end{array}$ & $\begin{array}{l}\text { All events' Nash } \\
\text { (including } \\
\text { interpolated } \\
\text { raingauges) }\end{array}$ & $\begin{array}{l}\text { All events' } L_{\mathrm{NP}} \\
\text { (including } \\
\text { interpolated } \\
\text { raingauges) }\end{array}$ & $\begin{array}{l}\text { Number of events } \\
\text { per catchment for } \\
\text { regionalization trials }\end{array}$ \\
\hline Number of events & 61 & 23 & 23 & 117 & 117 & 117 \\
\hline Tech (Pas du Loup) & $0.90(3)$ & 0.70 & 0.73 & 0.46 & 0.37 & 9 \\
\hline Têt (Marquixane) & $0.80(3)$ & 0.79 & 0.82 & 0.73 & 0.78 & 4 \\
\hline Réart (Saleilles) & $0.86(4)$ & 0.60 & 0.67 & 0.46 & 0.62 & 6 \\
\hline Verdouble (Tautavel) & $0.88(4)$ & 0.82 & 0.79 & 0.40 & 0.41 & 10 \\
\hline Agly (St Paul de F.) & $0.80(3)$ & 0.76 & 0.75 & 0.51 & 0.47 & 5 \\
\hline Salz (Cassaignes) & $0.88(3)$ & - & - & 0.60 & 0.55 & 11 \\
\hline Orbieu (Lagrasse) & $0.78(5)$ & 0.67 & 0.65 & 0.51 & 0.57 & 10 \\
\hline Cesse (Bize Minervois) & $0.80(3)$ & 0.80 & 0.87 & 0.44 & 0.42 & 11 \\
\hline Hérault (Ganges) & $0.76(3)$ & 0.56 & 0.76 & 0.65 & 0.71 & 4 \\
\hline Gardon (Anduze) & $0.75(6)$ & 0.86 & 0.88 & 0.63 & 0.71 & 10 \\
\hline Beaume (Rosières) & $0.77(3)$ & 0.49 & 0.71 & 0.60 & 0.68 & 6 \\
\hline Ardèche (Vogüé) & $0.83(5)$ & 0.87 & 0.85 & 0.86 & 0.88 & 7 \\
\hline Gapeau (Hyères) & $0.80(4)$ & 0.75 & 0.82 & 0.58 & 0.64 & 6 \\
\hline Réal Martin (La Crau) & $0.81(4)$ & 0.58 & 0.52 & 0.66 & 0.66 & 5 \\
\hline Aille (Vidauban) & $0.81(4)$ & 0.65 & 0.72 & 0.48 & 0.53 & 8 \\
\hline Nartuby (Trans en Pce) & $0.60(4)$ & - & - & 0.20 & 0.26 & 5 \\
\hline Mean & 0.80 & 0.67 & 0.72 & 0.54 & 0.56 & 7 \\
\hline Median & 0.80 & 0.70 & 0.75 & 0.55 & 0.59 & 7 \\
\hline
\end{tabular}

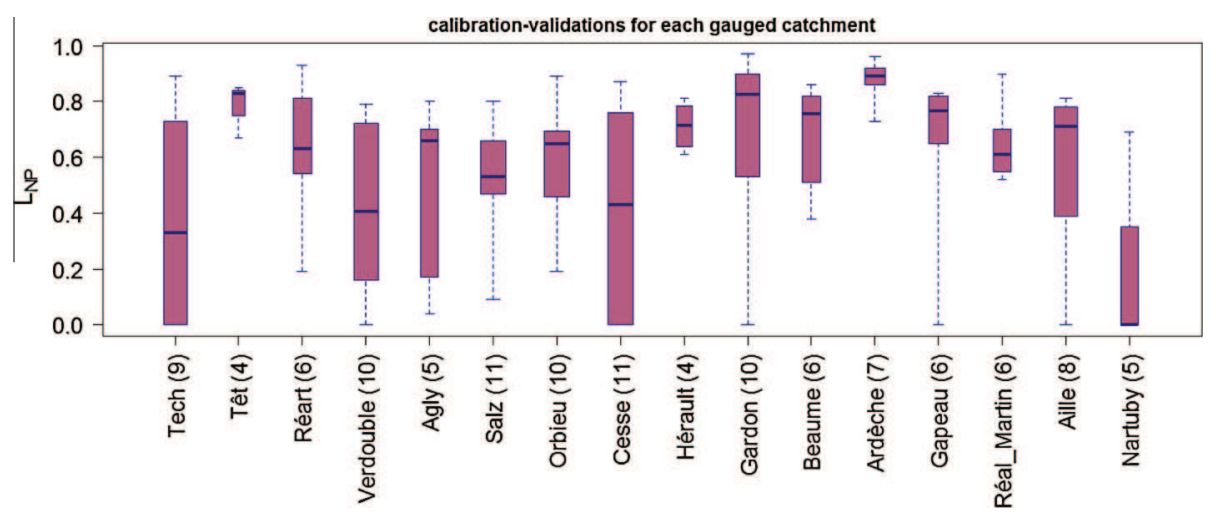

Fig. 4. MARINE model performances with calibrated parameter sets over the whole catchment-flood dataset, number of flash flood events between parentheses for each catchment.

several sources of error, and firstly to rainfall measurement errors that can be non negligibles in some cases, for example when radar or raingauge network or both have not seen a significant part of rainfall distribution explaining flood response (Garambois et al., 2015). Other significant sources of error can be: the hypothesis of time-independent parameter sets (and so uncertainty), the high flow gauging errors for several catchments.

It is important to notice that model performances are higher for catchments with an apparently more regular behaviour like the Ardèche or Gardon (Table 6). Regular behaviour means that the behaviour of the catchment seen by the model for validation events is close from the average behaviour found with calibration. A parameter set calibrated over several events is indeed supposed to reflect an average performance. For example, with similar performances in calibration (Nash $=0.88$ ) for the Salz and Verdouble catchments, for a large number of flood events (10) performances in validation are better for the Salz $\left(\mathrm{Nash}, L_{\mathrm{NP}}\right)=(0.60,0.55)$ than for the Verdouble (Nash, $\left.L_{\mathrm{NP}}\right)=(0.40,0.41)$. This might result from different hydrological behaviours between floods, maybe also depending on the variability of rainfall patterns in time and space. This joins the idea of unusual hydrological behaviour, i.e. a flood event not covered by the past calibration events (extrapolation case) (see e.g. (Singh and Bárdossy, 2012)); whereas with a regular behaviour, a new flood event is supposed to be covered by the past calibration events (interpolation case).

\subsection{Regionalization approaches}

In this section several combination of descriptors and number of donor catchments are tested. Results are compared to observations and "calibrated" simulations. The results and best performances presented here for flash flood events on Mediterranean catchments can depend on the selection of physical descriptors used to define the physical similarities and on the availability of soil and bedrock data in particular as it will be shown. That is why extrapolation to other region of the world might not be warranted. Moreover, stream gauging network density, meteorological and climatological indices are not considered in this study.

While making the choice during the regionalization process of an event physically based model for flash floods, several questions arise, as for continuous model regionalization (see e.g. (Oudin et al., 2008)), and are discussed below. 
3.2.1. When can a catchment be kept as donor for regionalization?

It is not straightforward to answer the question of catchments outliers, with a particular behaviour regarding the other catchments of a dataset. Modelling performances in calibration/validation for each catchment and physical meaning of catchment parameter sets can be considered as two important features of regionalization methods in the context of that study. First a threshold on model efficiency in cal/val mode could be used to exclude poorly modelled catchments for predictions at ungauged locations. Such a method would be very selective, for example a threshold of 0.7 would lead to consider only 4 donors (Table 6,6 th column), and so narrowing the possibilities for parameter sets and physical behaviours for ungauged catchments. Indeed, each catchment (parameter set) represents a possible operating point for MARINE model in the space defined by 5 parameters (Table 4), in other words a diversity of hydrological behaviours. We do not use a threshold on model efficiency hereafter.

The choice is made not to use 4 catchments as donors (Gapeau, Réal Martin, Aille, Nartuby) for the other 12 since pedologic data for these 4 catchments come from SIM model instead of soil surveys for the other 12 ( $\S 2.1$ ). Indeed, these data could have an impact on calibration process and consequently affect parameters' physical meaning.

One can wonder whether a relation between $\mathrm{cal} / \mathrm{val}$ and regionalization performances exists. To shed more light on this issue, Fig. 5 shows the relationship between the efficiency of calibrated parameter sets on donor gauged catchments and the efficiency of MARINE model on pseudo ungauged catchments, in the particular case of a single donor selected with spatial proximity. Results suggest that using a well-modelled catchment as donor does not warrant good performances on pseudo-ungauged catchments. However conversely, parameter sets from poorly-modelled catchments can produce higher performances when transferred to pseudo-ungauged catchment than in cal/val. The operating point in the model parameter space that it is possible to reach with cal/val can sometimes better reproduce ungauged catchment behaviour. This highlights the fluctuating quantity of hydrological information that is available in calibration events used to constrain parameter sets for a given gauged catchment.

\subsubsection{How many donor catchments should we consider for regionalization?}

In order to explore this issue, regionalization tests with a number increasing from 1 to 11 donor catchments are performed. Among the available catchment descriptors (cf. Table 3 ) the choice is made to present results for soil, bedrock and altitude difference descriptors. The use of other descriptors resulted in lower model efficiencies at ungauged locations.

Fig. 6 shows that for most regionalization methods based on similarity, the best performances are obtained with a few number of donor catchments between 2 and 4 . This number must depend on the descriptors used to calculate the similarity measure and their information content about hydrological controls. Using only one donor catchment decreases the performance of regionalization as increasing the number of gauged donor catchments. Increasing the number of donors results in selecting catchments with more and more distant hydrological behaviours regarding the catchment of interest. For a large number of donor catchments the efficiencies of the different regionalization schemes tend to sensibly increase, strong errors in peak flow simulation might be partially avoided by smoothing the model behaviour with different sources. Would those two trends be true for an even larger dataset? This is an open question; however, for all the combination of descriptors tested, the best performances are for 2-4 donors. In other words, for an ungauged catchment, the unicity of its behaviour may be better approximated by a parameter set calculated on few donors

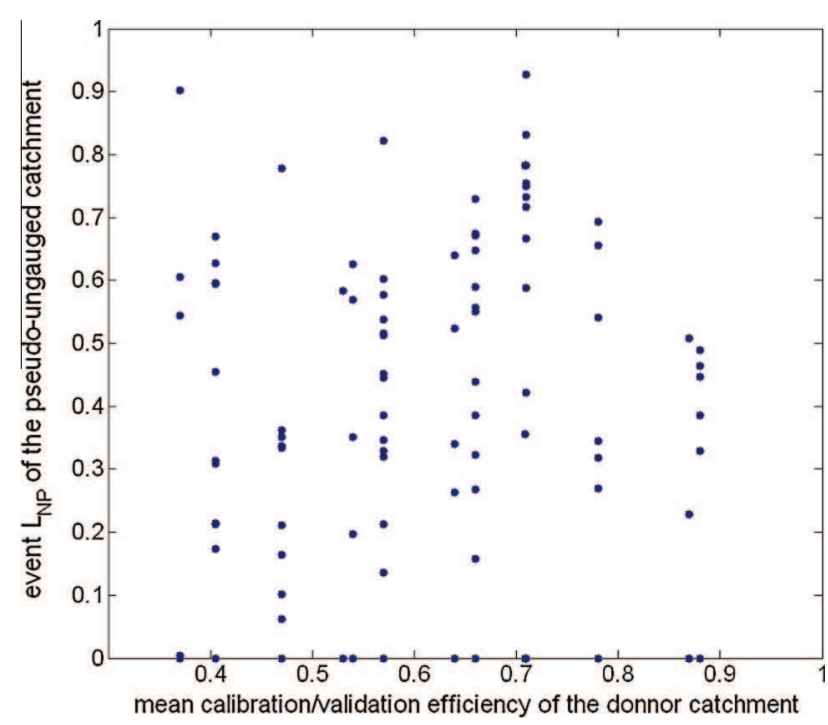

Fig. 5. Relationship between the mean cal/val efficiency of MARINE model for the donor gauged catchment and efficiency on pseudo ungauged catchment; case of the spatial proximity approach with one donor catchment. Number of event per catchment can be found in the last column of Table $6, L_{\mathrm{NP}}$ values lower than zero are plotted as zero.

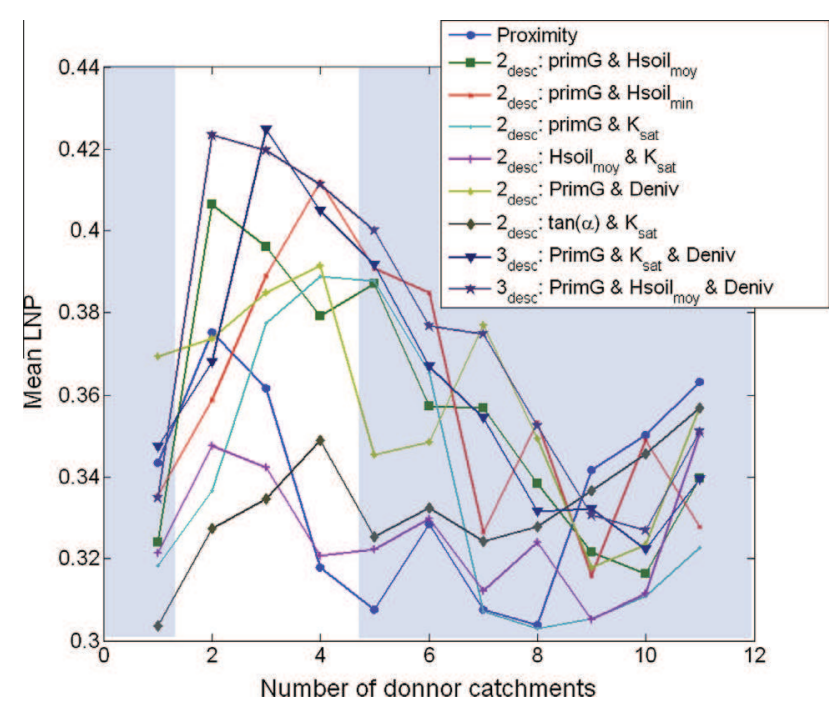

Fig. 6. Impact of the number of gauged catchment used for each regionalization scheme on averaged model efficiency. ( 8 methods $\times 117$ events $\times 12$ number of donors $=11,232$ simulations).

highlighting some physiographic and potentially similarities of behaviour, for this database.

\subsubsection{How to select information for regionalization?}

Selecting donor catchments to derive hydrological information to the site of interest is still an open question in regionalization context. Indeed, in function of the chosen combinations of descriptors or even the regionalization methods, different combinations of donor catchments can be obtained for an ungauged catchment. Proximity method and similarity method based on Hsoil mean and $K_{\text {sat }}$ produce the weaker performances (Fig. 6), whereas some combinations of descriptors containing the index of catchment's primary era bedrock (PrimG) seem the most relevant to select donor catchments. Increasing the number of descriptors from 2 to 3 slightly increases the performances but a fourth descriptor about soil, bedrock or topography is useless probably because it 
contains redundant information. Hereafter we will discuss in more details the results obtained with two combinations of descriptors involving PrimG.

Having examined the three above questions, the following choices are made for the regionalization:

- For gauged catchment selection, we do not use any threshold on model efficiency as regard to catchments' parameter set transferability.

- 4 catchments (Gapeau, Réal Martin, Aille, and Nartuby) are not considered as donors for the 12 other catchments since pedologic data come from a different source.

- Regionalization schemes with 2, 3 or 4 gauged donor catchments are preferred.

- Results produced by geographical proximity (2 donors) and the 2 methods presenting the best performances according to Fig. 6

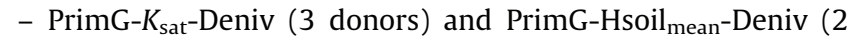
donors) - will be investigated in more details.

\subsection{Analysis of the efficiency of three simple regionalization schemes}

\subsubsection{General comparison}

Following the choices made earlier, in this section we examine in more details the results produced by three simple regionalization schemes (Table 7). Regionalization methods are assessed in terms of flood estimation. It is useful to recall that the methods are based on calibrated parameter sets presented in Table 4 . The $L_{\mathrm{NP}}$ cost function and its three components values are presented in Fig. 7. Statistics are calculated over all catchments. With median $L_{\mathrm{NP}}$ efficiencies of 0.47 for Reg2 and 0.45 for Reg3, these two regionalization schemes perform slightly under the range of cal/val whose median $L_{N P}$ is 0.59 for the 117 flood events. For the two similarity approaches flood hydrographs features are acceptable.

Table 7

Regionalization schemes for MARINE model detailed in this paper.

\begin{tabular}{|c|c|c|c|}
\hline $\begin{array}{l}\text { Regionalization } \\
\text { method }\end{array}$ & Kind & Attributes & $\begin{array}{l}\text { Number } \\
\text { of } \\
\text { donors }\end{array}$ \\
\hline [Reg1] & Proximity & Geographical proximity & 2 \\
\hline [Reg2] & Similarity & $\begin{array}{l}\text { Percentage of catchment area on } \\
\text { Primary bedrock (PrimG), spatial } \\
\text { average of saturated hydraulic } \\
\left.\text { conductivity ( } K_{\text {sat }}\right) \text { and altitude } \\
\text { difference (Deniv) }\end{array}$ & 3 \\
\hline [Reg3] & Similarity & $\begin{array}{l}\text { Percentage of catchment area on } \\
\text { Primary bedrock (PrimG), spatial } \\
\text { average of soil depth (Hsoil } \\
\text { and altitude difference (Deniv) }\end{array}$ & 2 \\
\hline
\end{tabular}

Concerning peak flow, the median efficiency is 0.57 for Reg2 and 0.51 for Reg3; for peak timing median $1-d T_{p}$ is 0.52 for Reg2 and 0.58 for Reg3. Median Nash efficiencies are slightly lower with 0.31 and 0.37 . However in the case of flash floods, Nash efficiencies can easily collapse; for example when a very peaky hydrograph is shifted in time. The approach with geographical proximity Reg 1 is less efficient with a $L_{\mathrm{NP}}$ of 0.37 .

The distribution of performances for pseudo ungauged catchment for the three regionalization methods is acceptable with rather narrow interquartile range and best catchment's $L_{\mathrm{NP}}$ above 0.7 . The few outliers at the low end of box plots might indicate that methods' robustness could be improved. It is interesting to notice that for the three regionalization methods, these low performances occurred for the Nartuby catchment (see Fig. 8) where modelling is not easy even in cal/val as explained before (cf. Section 3.1), and the Réart catchment. For this particular catchment that behaves like an intermittent river but where cal/val results were better, it seems that there are no good donor catchments within the dataset.

In summary, regionalized parameter sets with these 3 methods based on model calibration yield to encouraging results as regards to standard scores obtained for each catchment in cal/val over the dataset (Fig. 8). Moreover the decrease of about 10 percents in performances between cal/val and regionalization is comparable to what is found in the literature for continuous models. In the following, we investigate in more details MARINE model performances over each catchment and the donor catchments selected with the regionalization methods.

\subsubsection{Catchment performances}

Fig. 8 highlights some cases where performances of regionalization methods are largely under cal/val performances (Réart, Hérault, Ardèche, Réal Martin). For those catchments this might be either the descriptors used for regionalization either the possible donor catchments within our dataset that do not contain enough relevant hydrological information to constrain MARINE model and reproduce particular catchment behaviour. For the 12 other catchments average regionalization efficiency is close to cal/val performances (for example: Verdouble, Gardon, Beaume) which is a very encouraging result given the difficulties involved in flash flood modelling and forecasting.

$\mathrm{Cal} / \mathrm{val}$ results are expected to represent the upper limit for regionalization. But in some cases, regionalization slightly outperforms cal/val: the Verdouble, the Agly, the Gardons and the Cesse. This could question the "optimality" of the operating point found in the parameter space during calibration process. In the case of the Gardons, cal/val and regionalization efficiencies are higher than for the Verdouble, the Agly and the Cesse, approximately of 0.7. In

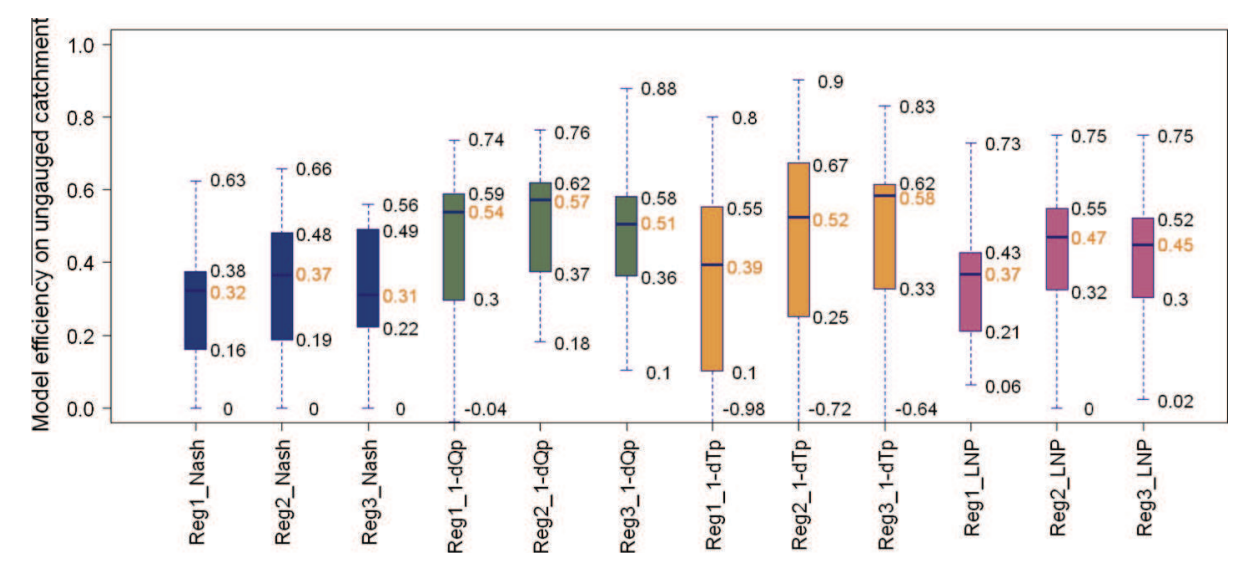

Fig. 7. Comparison of the efficiency in terms of (Nash), $\left(1-d Q_{p}\right),\left(1-d T_{p}\right)$ and $\left(L_{\mathrm{NP}}\right)$ for three regionalization schemes: Geographical proximity $(2$ donors $)$ [Reg1], PrimG- $K_{\mathrm{sat}}{ }^{-}$ Deniv (3 donors) [Reg2] and PrimG-Hsoil mean-Deniv (2 donors) [Reg3]. 


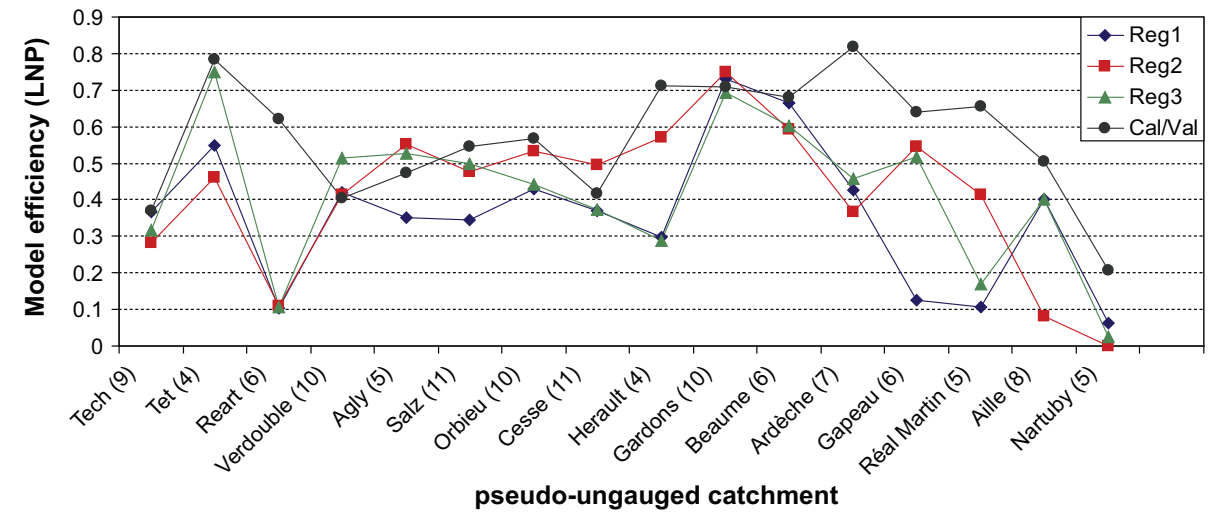

Fig. 8. Efficiency in terms of $L_{\mathrm{NP}}$ for each pseudo ungauged catchment for three regionalization schemes: Geographical proximity (2 donors) [Reg1], PrimG- $K_{\text {sat-Deniv }}$ (3

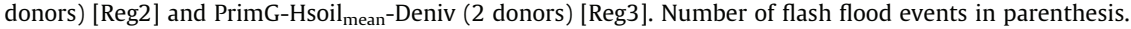

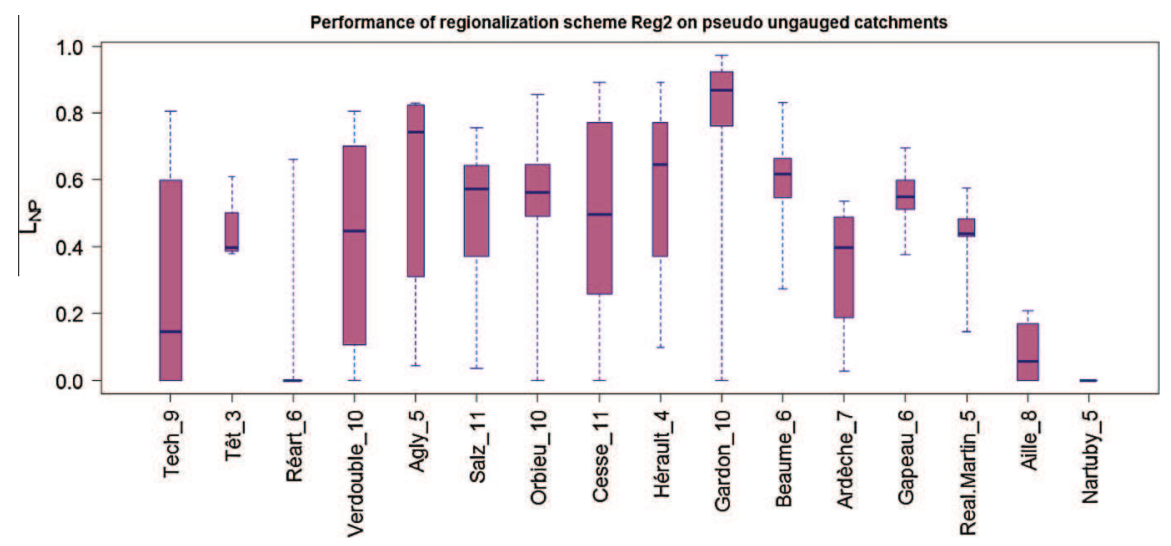

Fig. 9. Boxplot of MARINE model performances over the whole catchment-flood dataset, parameter sets are determined with Reg2, i.e. similarity method with PrimG- $K_{\text {sat }}{ }^{-}$ Deniv (3 donors) [Reg2]. Number of flash flood events specified after each catchment's name.

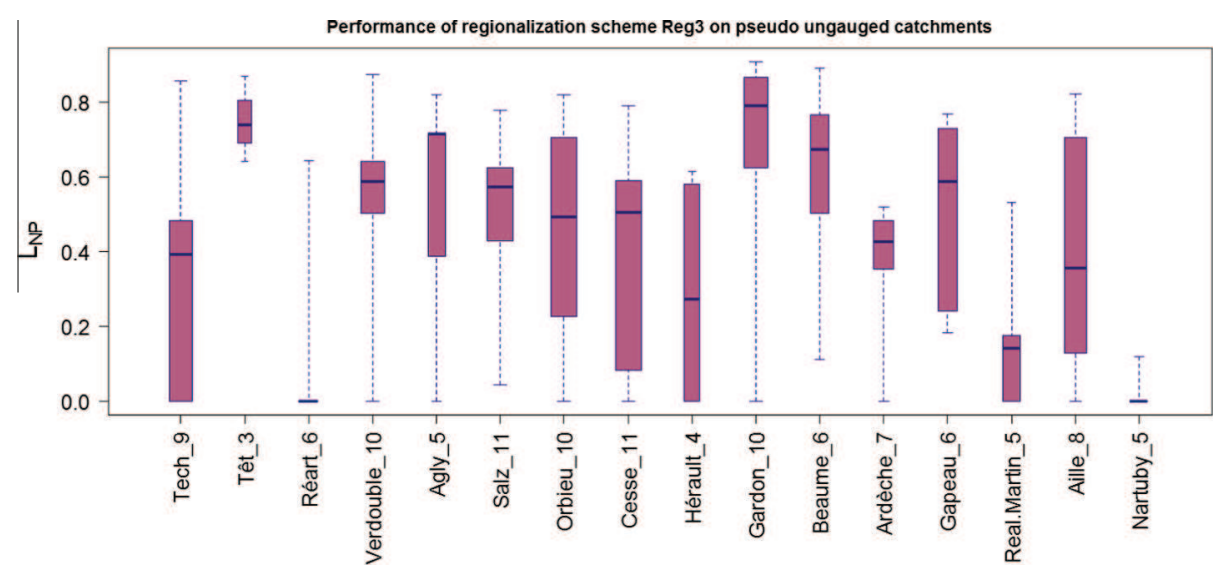

Fig. 10. Boxplot of MARINE model performances over the whole catchment-flood dataset, parameter sets are determined with Reg3, i.e. similarity method with PrimG-

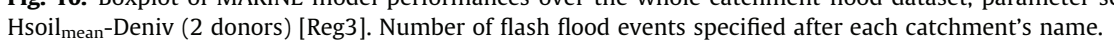

the cases of Agly and Verdouble, or the Cesse which a karstic catchment, the lack of flash flood events and/or relevant hydrological information for calibration can be pointed out. In the case of the Gardons, slightly more relevant hydrological information is found with regionalization than with calibration.

In other words, for some catchments flood records might not be rich enough regarding hydrological information to calibrate parameter sets able to predict a large spectrum of flash floods.

\subsubsection{Event performances}

In the section above, it is shown that for 12 catchments out of 16 , the average regionalization efficiency is close to cal/val performances. The number of events in function of the $L_{\mathrm{NP}}$ values is presented for each catchment in Fig. 4 for calibrated parameter sets and in Fig. 9 and Fig. 10 for the parameter sets obtained with similarity approaches.

Performances degradation from cal/val to regionalization can be depicted in terms of event efficiencies for each catchment for 


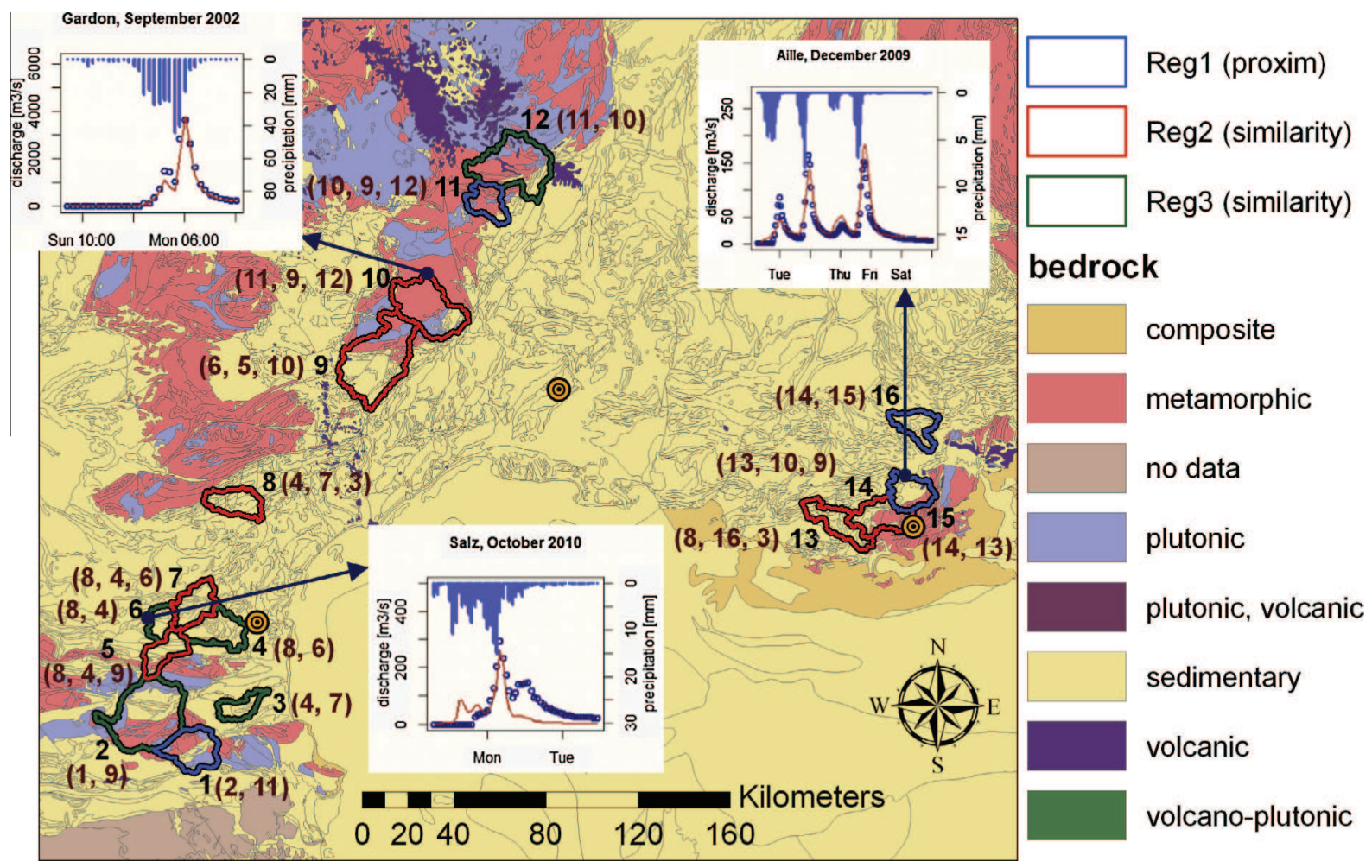

Fig. 11. Pseudo ungauged catchments numbered in black with the regionalization scheme which performed the best (catchment boundary in blue, red or green) and the donor catchments (brown numbers). Simplified bedrock composition at the background. Hydrographs simulated with regionalized parameter sets of Table 8 (blue dots $=$ observations, red line $=$ simulated discharge). (For interpretation of the references to colour in this figure legend, the reader is referred to the web version of this article.)

Table 8

Comparison of calibrated and regionalized parameter sets for the best regionalization scheme performance (Reg2 if 3 donors, Reg3 if 2 donors).

\begin{tabular}{|c|c|c|c|c|c|c|c|c|c|c|c|}
\hline $\begin{array}{l}\text { Pseudo ungauged } \\
\text { catchment }\end{array}$ & Donor catchments & $\begin{array}{l}C_{Z}(-) \\
\text { Cal. }\end{array}$ & $\begin{array}{l}C_{Z}(-) \\
\text { Reg. }\end{array}$ & $\begin{array}{l}C_{K}(-) \\
\text { Cal. }\end{array}$ & $\begin{array}{l}C_{K}(-) \\
\text { Reg. }\end{array}$ & $\begin{array}{l}C_{\text {KSS }} \\
(-) \\
\text { Cal. }\end{array}$ & $\begin{array}{l}C_{\mathrm{KSS}} \\
(-) \\
\text { Reg. }\end{array}$ & $\begin{array}{l}K_{D 1} \\
\left(\mathrm{~m}^{1 / 3} / \mathrm{s}\right) \\
\text { Cal. }\end{array}$ & $\begin{array}{l}K_{D 1} \\
\left(\mathrm{~m}^{1 / 3} / \mathrm{s}\right) \\
\text { Reg. }\end{array}$ & $\begin{array}{l}K_{D 2} \\
\left(\mathrm{~m}^{1 / 3} / \mathrm{s}\right) \\
\text { Cal. }\end{array}$ & $\begin{array}{l}K_{D 2} \\
\left(\mathrm{~m}^{1 / 3} / \mathrm{s}\right) \\
\text { Reg. }\end{array}$ \\
\hline Tech (\#1) & [Têt(\#2), Beaume(\#11)] & 4.3 & 5.5 & 11.0 & 9.7 & 1515 & 4908 & 5.0 & 19.6 & 3.2 & 12.6 \\
\hline Têt (\#2) & [Tech(\#1), Hérault(\#9)] & 6.1 & 3.8 & 19.8 & 16.2 & 10,000 & 4031 & 11.8 & 7.5 & 3.4 & 4.6 \\
\hline Réart (\#3) & [Verdouble(\#4), Orbieu(\#7)] & 4.3 & 1.3 & 15.0 & 15.0 & 1242 & 6004 & 5.7 & 6.3 & 30.0 & 3.3 \\
\hline Verdouble (\#4) & [Cesse(\#8), Salz(\#6)] & 1.3 & 1.2 & 15.0 & 11.6 & 4486 & 8603 & 5.0 & 5.0 & 4.0 & 5.9 \\
\hline Agly (\#5) & [Cesse(\#8), Verdouble(\#4), Hérault(\#9)] & 1.6 & 2.1 & 20.0 & 13.6 & 4304 & 6322 & 7.5 & 6.1 & 2.2 & 5.1 \\
\hline Salz (\#6) & [Cesse(\#8), Verdouble(\#4)] & 1.0 & 1.3 & 20.0 & 10.9 & 5595 & 7592 & 5.0 & 5.0 & 5.0 & 5.3 \\
\hline Orbieu (\#7) & [Cesse(\#8), Verdouble(\#4), Salz(\#6)] & 1.3 & 1.2 & 15.0 & 12.4 & 10,000 & 7274 & 9.1 & 5.0 & 2.0 & 5.3 \\
\hline Cesse (\#8) & [Verdouble(\#4), Orbieu(\#7), Réart(\#3)] & 1.3 & 2.2 & 7.7 & 14.9 & 10,000 & 6577 & 5.0 & 7.9 & 6.3 & 10.5 \\
\hline Hérault (\#9) & [Salz(\#6), Agly(\#5), Gardons(\#10)] & 3.6 & 2.4 & 17.8 & 16.5 & 4764 & 4843 & 8.2 & 8.1 & 5.0 & 5.9 \\
\hline Gardon (\#10) & [Beaume(\#11), Hérault(\#9), Ardèche(\#12)] & 4.6 & 4.1 & 10.3 & 9.4 & 4540 & 4472 & 11.7 & 13.0 & 9.7 & 12.6 \\
\hline Beaume (\#11) & [Gardons(\#10), Hérault(\#9), Ardèche(\#12)] & 5.3 & 3.9 & 7.4 & 13.1 & 3712 & 4706 & 21.4 & 9.6 & 14.7 & 8.5 \\
\hline Ardèche (\#12) & [Beaume(\#11), Gardons(\#10)] & 3.4 & 5.0 & 2.1 & 8.7 & 4891 & 4105 & 10.0 & 16.8 & 19.1 & 12.3 \\
\hline Gapeau (\#13) & [Cesse(\#8), Nartuby(\#16), Réart(\#3)] & 1.2 & 2.3 & 4.8 & 11.2 & 1200 & 5157 & 14.0 & 10.8 & 20.8 & 14.1 \\
\hline Réal Martin (\#14) & [Gapeau(\#13), Gardons(\#10), Hérault(\#9)] & 1.3 & 3.0 & 3.0 & 10.4 & 415 & 3299 & 19.7 & 11.5 & 5.0 & 12.6 \\
\hline Aille (\#15) & [Réal Martin(\#14), Gapeau(\#13)] & 0.4 & 1.2 & 4.0 & 4.1 & 715 & 884 & 31.2 & 16.3 & 7.0 & 14.4 \\
\hline Nartuby (\#16) & [Réal Martin(\#14), Aille(\#15)] & 1.1 & 0.9 & 10.5 & 3.4 & 4525 & 537 & 22.0 & 24.4 & 5.0 & 5.8 \\
\hline
\end{tabular}

two combinations of descriptors. Interestingly, for all catchments except the Real Martin, the Nartuby and the Ardèche, there is at least one event simulated with a $L_{\mathrm{NP}}$ greater than 0.6 for the two regionalization schemes tested (Fig. 9 and Fig. 10). For several catchments, flood event performances in regionalization can be greater than $L_{\mathrm{NP}}=0.8$. From the comparison between Figs. 9, 10 and 4 and using Fig. 8, several cases can be highlighted:

- Catchments where cal/val results and regionalization results are similar; for example the Salz, the Gardons or the Beaume. For the Gardons, the donor catchments selected with the three methods (Table 9) present a bedrock composition mainly metamorphic and plutonic and therefore similar to the receptor bedrock (Fig. 11). This is also true for the Beaume catchment. The same comment can be made for the Salz: the two donors selected both with Reg3 and Reg 2, the Cesse and the Verdouble, present bedrocks that are mainly sedimentary. For those cases, receptor and donor catchments have comparable $C_{Z}$ values in calibration (cf. Table 3 ). This means that the regionalization schemes and catchment descriptors combinations are pertinent. Moreover this means that there exist good donor catchments within the dataset. There is also the example of the Nartuby, which is a poorly modelled catchment in cal/val and in regionalization, probably because it is mostly karstic. 
Table 9

Combinations of donor catchments given pseudo ungauged catchment for each of the 3 regionalization schemes: Geographical proximity (2 donors) [Reg1], PrimG- $K_{\text {sat }}-$ Deniv ( 3 donors) [Reg2] and PrimG-Hsoil mean-Deniv (2 donors) [Reg3]. Catchment number (\#).

\begin{tabular}{|c|c|c|c|}
\hline Pseudo ungauged & Proximity donors & PrimG $K_{\text {sat }}$ Deniv (3 donors) & PrimG Hsoil $l_{\text {mean }}$ Deniv (2 donors) \\
\hline $\operatorname{Tech}(\# 1)$ & [Têt(\#2), Réart(\#3)] & [Têt(\#2), Agly(\#5), Hérault(\#9)] & [Têt(\#2), Beaume(\#11)] \\
\hline Têt(\#2) & {$[\operatorname{Tech}(\# 1), \operatorname{Agly}(\# 5)]$} & [Tech(\#1), Agly(\#5), Hérault(\#9)] & [Tech(\#1), Hérault(\#9)] \\
\hline Réart(\#3) & [Verdouble(\#4), Tech(\#1)] & [Cesse(\#8), Verdouble(\#4), Orbieu(\#7)] & [Verdouble(\#4), Orbieu(\#7)] \\
\hline Verdouble(\#4) & [Orbieu(\#7), Salz(\#6)] & [Cesse(\#8), Orbieu(\#7), Réart(\#3)] & {$[$ Cesse(\#8), Salz(\#6)] } \\
\hline Agly(\#5) & [Orbieu(\#7), Salz(\#6)] & [Cesse(\#8), Verdouble(\#4), Hérault(\#9)] & [Cesse(\#8), Hérault(\#9)] \\
\hline Salz(\#6) & [Orbieu(\#7), Agly(\#5)] & [Cesse(\#8), Verdouble(\#4), Orbieu(\#7)] & [Cesse(\#8), Verdouble(\#4)] \\
\hline Orbieu(\#7) & [Verdouble(\#4), Salz(\#6)] & [Cesse(\#8), Verdouble(\#4), Salz(\#6)] & [Verdouble(\#4), Réart(\#3)] \\
\hline Cesse(\#8) & [Verdouble(\#4), Orbieu(\#7)] & [Verdouble(\#4), Orbieu(\#7), Réart(\#3)] & [Verdouble(\#4), Salz(\#6)] \\
\hline Hérault(\#9) & [Beaume(\#11), Gardons(\#10)] & [Salz(\#6), Agly(\#5), Gardons(\#10)] & [Agly(\#5), Ardèche(\#12)] \\
\hline Gardons(\#10) & [Beaume(\#11), Hérault(\#9)] & [Beaume(\#11), Hérault(\#9), Ardèche(\#12)] & [Beaume(\#11), Ardèche(\#12)] \\
\hline Beaume(\#11) & [Gardons(\#10), Ardèche(\#12)] & [Gardons(\#10), Hérault(\#9), Ardèche(\#12)] & [Gardons(\#10), Ardèche(\#12)] \\
\hline Ardèche(\#12) & [Beaume(\#11), Gardons(\#10)] & [Beaume(\#11), Gardons(\#10), Hérault(\#9)] & [Beaume(\#11), Gardons(\#10)] \\
\hline Gapeau(\#13) & [Réal Martin(\#14), Aille(\#15)] & [Cesse(\#8), Nartuby(\#16), Réart(\#3)] & [Réal Martin(\#14), Aille(\#15)] \\
\hline Réal Martin(\#14) & [Aille(\#15), Gapeau(\#13)] & [Gapeau(\#13), Gardons(\#10), Hérault(\#9)] & [Aille(\#15), Gapeau(\#13)] \\
\hline Aille(\#15) & [Réal Martin(\#14), Gapeau(\#13)] & [Réal Martin(\#14), Hérault(\#9), Ardèche(\#12)] & [Réal Martin(\#14), Gapeau(\#13)] \\
\hline Nartuby(\#16) & [Réal Martin(\#14), Aille(\#15)] & [Cesse(\#8), Verdouble(\#4), Réart(\#3)] & [Orbieu(\#7), Réart(\#3)] \\
\hline
\end{tabular}

- Catchments where cal/val results are good and only one regionalization scheme is efficient; for example the Têt [Reg3], the Orbieu [Reg2], the Hérault [Reg2], the Real Martin [Reg2], the Aille [Reg3]. Once again, the calibrated $C_{Z}$ values are similar between receptor and donor catchments thanks to bedrock descriptors. But hydrological information might be better transferred depending on the choice of physiographic descriptors, $K_{\text {sat }}$ for Reg2 and Hsoil $l_{\text {mean }}$ for Reg3. The existence of good donors within the dataset is also important. Indeed, for the Réal Martin the bedrock is sedimentary for a half of the area and metamorphic for the other half, and the donors selected with the similarity method Reg2 have contrasted bedrocks and $C_{Z}$.

- Catchments where cal/val is satisfying but no regionalization scheme is efficient like for the Ardèche or the Réart. This can be attributable to the lack of donor catchments, at least for the combination of descriptors tested. Indeed, the best regionalization method gives a $C_{Z}$ of 1.3 for the Réart, whereas the calibrated value was of 4.3 , as shown in Table 8 which presents for each catchment the values of the parameter sets issued from calibration and regionalization.

- Catchments where regionalization outperforms cal/val such as the Verdouble [Reg3], the Cesse [Reg2] or Agly (Reg2 and Reg3). As stated before the calibrated parameter sets from donor catchments might contain more hydrological information than the events available for at site calibration.

For a given pseudo ungauged catchment, it is not the same flood events that are best simulated for each regionalization scheme since the parameter sets obtained are not the same. The behaviour of a catchment may change from one flood to another, depending on the resonance between spatial catchment properties and the spatial and temporal repartition of rainfall. This emphasizes the difficulty of predicting a large spectrum of flash flood behaviours for a given catchment and hydrological model complexity with a single parameter set.

\subsection{Which hydrological information is best transferred?}

To examine whether several spatial patterns exist in the performance of regionalization methods, the best regionalization solutions with MARINE model for each catchment are shown in Fig. 11, along with bedrock composition on which the regionalization schemes with similarity (Reg2 and Reg3) are based. For this dataset and our process oriented model, the physical similarity approach performs better than the proximity approach and there is no clear spatial pattern in donor catchments localization between the three regionalization methods tested.

The value of regionalized parameter sets are presented with calibrated values for each catchment in Table 8. As stated in $\S 2.2$ $C_{Z}$ determines catchment storage capacity and has a great influence on peak discharge and runoff coefficient. The regionalized values of this parameter are close to calibrated ones for most catchments. When $C_{Z}$ calibration and regionalization values are too different, performances of regionalization methods are largely under cal/val performances, like for the Réart or the Ardèche. Moreover the catchments with similar $C_{Z}$ exchange their parameter sets. These catchments can be located in a geographical zone with similar properties or hydrological landscapes responsible for comparable hydrological behaviours: for example the Hérault, Gardon, Beaume or Ardèche (\#9, 10, 11, 12 on Fig. 11); or another group composed of the Verdouble, Agly, Salz, Orbieu, Cesse (\#4, 5, 6, 7, 8 on Fig. 11). Interestingly, the physiographic descriptor about primary bedrock reveals to be a powerful indicator to constrain MARINE model parameters and especially $C_{Z}$. It can be related to bedrock characteristics which might influence significantly flood water balance as already explained in $\S 2.3$ and $\S 3.3$ and detailed in Garambois et al., 2013.

\section{Conclusions}

This paper investigates the regionalization of MARINE process oriented model in the case of 117 recent flash floods of the French Mediterranean region. MARINE model performances in $\mathrm{cal} / \mathrm{val}$ are ranging from $\left(\mathrm{Nash} ; L_{\mathrm{NP}}\right)=(0.2 ; 0.26)$ to $(0.86 ; 0.88)$ with a mean (Nash; $\left.L_{\mathrm{NP}}\right)$ of $(0.54 ; 0.56)$. Cal/val is first compared to the simplest regionalization scheme consisting in spatial proximity method with one donor. Results show that using a well-modelled catchment as donor does not always produce good performances on pseudo-ungauged catchments and conversely, parameter sets from poorly-modelled catchments can produce higher performances when transferred to pseudo-ungauged catchment. Spatial proximity and similarity approaches with several combinations of descriptors are then tested for one to 12 donor catchments. Using 2-4 donor catchments gives the highest performances and the combinations of descriptors containing information about primary bedrock are the most relevant. Physiographic similarity approaches produce better results than the proximity approach for our flash flood data set.

Encouraging results are obtained with two similarity approaches based on physiographic descriptors with two and three donor catchments. There is only a small decrease of performances 
from cal/val with $L_{\mathrm{NP}}=0.59$ to regionalization with $L_{\mathrm{NP}}=0.47$ and 0.45 for these two methods.

Regionalization performances were then examined for each catchment and show the need of good donor catchments, i.e. with similar hydrological behaviours, within the dataset given pertinent combinations of descriptors. Interestingly, for some catchments regionalization outperforms $\mathrm{cal} / \mathrm{val}$. In that case, this suggests that more (relevant) hydrological information can be available from donor catchments than the events available for at site calibration. The same analysis can be made according to the results of regionalization with the spatial proximity method and one donor.

Event performances in regionalization are encouraging and for 13 catchments out of 16 there is at least one flood event simulated with a $L_{\mathrm{NP}}$ greater than 0.6 and sometimes 0.8. Different model behaviours are simulated through regionalization process and reproduce a mean catchment behaviour. The actual catchment behaviour however may change from one flood to another, which is probably why regionalization is found to be easier for catchment with an apparently more regular behaviour (as defined in $\S 3.1$ ). This emphasizes the difficulty of predicting a large spectrum of flash flood behaviours for a given catchment and a given hydrological model complexity with a single parameter set.

The soil depth multiplicative constant $C_{Z}$ is the most influent parameter of the MARINE model. As explained in $\S 2.3, C_{Z}$ has a significant impact on water balance within the model and values larger than 1 indicates that catchment storage capacity needs to be increased for flash flood modelling purpose. Indeed, percolation in bedrock might play a significant role on flash flood water balance.

The $C_{Z}$ greater than one found for catchment areas developing on metamorphic or plutonic bedrocks are in agreement with the results of Vannier et al. (2013). Probably because of its high influence, $C_{Z}$ is rather well constrained by the two similarity approaches in regionalization. The unicity of catchments might be well accounted through the use of topography, soil and bedrock descriptors. This study demonstrates the predictive power of bedrock descriptor for regionalization in the case of Mediterranean flash floods.

It would be interesting to test this approach on a larger dataset and for other regions of the world with different physiographic characteristics and climate. Further studies could investigate the use of homogeneous regions in terms of climatology, meteorological indices, and particularly indices about extreme rainfall statistics at different space-time scales. This could be a way to search donor catchments in a hydrological neighbourhood with even more physical meaning. The uncertainties from rainfall and initial soil water contents could also be propagated into regionalization process for example with regionalization methods developed in probabilistic frameworks (see e.g. (Smith et al., 2014)).

\section{Acknowledgments}

The authors gratefully acknowledge the financial support by the French central flood forecast service SCHAPI and data supply by the SCHAPI, and regional flood forecast services SPCMO, SPCGD and SPCME.

\section{Appendix A}

See Table 1.

\section{References}

Abdulla, F.A., Lettenmaier, D.P., 1997. Development of regional parameter estimation equations for a macroscale hydrologic model. J. Hydrol. 197, 230 257.
Bandaragoda, C., Tarboton, D.G., Woods, R., 2004. Application of TOPNET in the distributed model intercomparison project. J. Hydrol. 298, 178-201.

Bárdossy, A., 2007. Calibration of hydrological model parameters for ungauged catchments. Hydrol. Earth Syst. Sci. J1 - HESS 11, 703-710.

Borga, M., Gaume, E., Creutin, J.D., Marchi, L., 2008. Surveying flash floods: gauging the ungauged extremes. Hydrol. Process, 22, 3883-3885.

Braud, I., Roux, H., Anquetin, S., Maubourguet, M.-M., Manus, C., Viallet, P., Dartus, D., 2010. The use of distributed hydrological models for the Gard 2002 flash flood event: analysis of associated hydrological processes. J. Hydrol. 394, 162181.

Castaings, W., Dartus, D. Le Dimet, F.-X., Saulnier, G.-M.,2009. Sensitivity analysis and parameter estimation for distributed hydrological modeling: potential of variational methods. Hydrol. Earth Syst. Sci. J1 - HESS 13, 503-517.

Delrieu, G., Ducrocq, V., Gaume, E., Nicol, J., Payrastre, O., Yates, E., Kirstetter, P.-E., Andrieu, H., Ayral, P.-A., Bouvier, C., Creutin, J.-D., Livet, M., Anquetin, S., Lang M. Neppel, L., Obled, C., Parent-du-Châtelet, J., Saulnier, G.-M., Walpersdorf, A. Wobrock, W., 2005. The catastrophic flash-flood event of 8-9 September 2002 in the Gard Region, France: a first case study for the Cévennes-Vivarais Mediterranean hydrometeorological observatory. J. Hydrometeorol. 6, 34-52.

Delrieu, G., Bonnifait, L., Kirstetter, P.-E., Boudevillain, B., 2014a. Dependence of radar quantitative precipitation estimation error on the rain intensity in the Cévennes region, France. Hydrol. Sci. J. 59, 1308-1319.

Delrieu, G., Wijbrans, A., Boudevillain, B., Faure, D., Bonnifait, L., Kirstetter, P.-E., 2014b. Geostatistical radar-raingauge merging: a novel method for the quantification of rain estimation accuracy. Adv. Water Resour. 71, 110-124.

Francés, F., Vélez, J.I., Vélez, J.J., 2007. Split-parameter structure for the automatic calibration of distributed hydrological models. J. Hydrol. 332, 226-240.

Garambois, P.A., 2012. Etude régionale des crues éclair de l'arc méditerranéen français. Elaborations de méthodologies de transfert à des bassins versants non jaugés (PhD thesis). Available at: <http://hydrologie.org/THE/GARAMBOIS_P-A. pdf>.

Garambois, P.A., Roux, H., Larnier, K., Castaings, W., Dartus, D., 2013. Characterization of process oriented hydrologic model behaviour with temporal sensitivity analysis for flash floods in Mediterranean catchments. Hydrol. Earth Syst. Sci. 17, 2305-2322. http://dx.doi.org/10.5194/hess-172305-2013.

Garambois, P.A., Larnier, K., Roux, H., Labat, D., Dartus, D., 2014. Analysis of flash flood-triggering rainfall for a process-oriented hydrological model. Atmos. Res. 137, 14-24. http://dx.doi.org/10.1016/j.atmosres.2013.09.016.

Garambois, P.A., Larnier, K., Roux, H., Labat, D., Dartus, D., 2015. Characterisation of catchment behaviour and rainfall selection for the regionalisation of flash flood hydrological models: catchments of the eastern Pyrenees. Hydrol. Sci. J. 60 (3), 424-447. http://dx.doi.org/10.1080/02626667.2014.909596.

Gaume, E., Bain, V., Bernardara, P., Newinger, O., Barbuc, M., Bateman, A Blaskovicová, L., Blöschl, G., Borga, M., Dumitrescu, A., Daliakopoulos, I., Garcia, J., Irimescu, A., Kohnova, S., Koutroulis, A., Marchi, L., Matreata, S., Medina, V., Preciso, E., Sempere-Torres, D., Stancalie, G., Szolgay, J., Tsanis, I., Velasco, D., Viglione, A., 2009. A compilation of data on European flash floods. J. Hydrol. 367, 70-78.

Gottschalck, L., Jensen, J.L., Lundquist, R., Solantie, R., Tollan, A., 1979. Hydrologic regions in the Nordic countries. Nord. Hydrol., 273-286

Habets, F., Boone, A., Champeaux, J.L., Etchevers, P., Franchistéguy, L., Leblois, E. Ledoux, E., Le Moigne, P., Martin, E., Morel, S., Noilhan, J., Quintana Seguì, P. Rousset-Regimbeau, F., Viennot, P., 2008. The SAFRAN-ISBA-MODCOU hydrometeorological model applied over France. J. Geophys. Res. 113.

Hundecha, Y., Bárdossy, A., 2004. Modeling of the effect of land use changes on the runoff generation of a river basin through parameter regionalization of a watershed model. J. Hydrol. 292, 281-295.

IH, 1999. [institute of hydrology], Flood Estimation Handbook. Wallingford, UK.

James, L.D., 1972. Hydrologic modeling, parameter estimation, and watershed characteristics. J. Hydrol. 17, 283-307.

Jonkman, S.N., 2005. Global perspectives on loss of human life caused by floods. Nat. Hazards 34, 151-175.

Kay, A.L., Jones, D.A., Crooks, S.M., Calver, A., Reynard, N.S., 2006. A comparison of three approaches to spatial generalization of rainfall-runoff models. Hydrol. Process. 20, 3953-3973.

Kokkonen, T.S., Jakeman, A.J., Young, P.C., Koivusalo, H.J., 2003. Predicting daily flows in ungauged catchments: model regionalization from catchment descriptors at the Coweeta Hydrologic Laboratory, North Carolina. Hydrol. Process. 17, 2219-2238.

Manus, C., Anquetin, S., Braud, I., Vandervaere, J.-P., Creutin, J.-D., Viallet, P., Gaume, E., 2009. A modeling approach to assess the hydrological response of small Mediterranean catchments to the variability of soil characteristics in a context of extreme events. Hydrol. Earth Syst. Sci. J1 - HESS 13, 79-97.

Marchandise, A., Viel, C., 2009. Utilisation des indices d'humidité de la chaîne Safran-Isba-Modcou de Météo-France pour la vigilance et la prévision opérationnelle des crues. La Houille Blanche, 35-41.

McIntyre, N., Lee, H., Wheater, H., Young, A., Wagener, T., 2005. Ensemble predictions of runoff in ungauged catchments. Water Resour. Res. 41.

Merz, R., Blöschl, G., 2004. Regionalisation of catchment model parameters. J. Hydrol. 287, 95-123.

Merz, R., Blöschl, G., Parajka, J., 2006. Regionalization methods in rainfall-runoff modelling using large catchment samples. In: IAHS Publication 307 Large Sample Basin Experiments for Hydrological Model Parameterization: Results of the Model Parameter Experiment (MOPEX) 2006, pp. 117-125. 
Moussa, R., 2010. When monstrosity can be beautiful while normality can be ugly: assessing the performance of event-based flood models. Hydrol. Sci. J. 55, 10741084.

Moussa, R., Chahinian, N., Bocquillon, C., 2007. Distributed hydrological modelling of a Mediterranean mountainous catchment - Model construction and multisite validation. J. Hydrol. 337, 35-51.

Oudin, L., Andréassian, V., Perrin, C., Michel, C., Le Moine, N., 2008. Spatial proximity, physical similarity, regression and ungaged catchments: a comparison of regionalization approaches based on 913 French catchments. Water Resour. Res. 44, W03413.

Parajka, J. Merz, R. Blöschl, G., 2005. A comparison of regionalisation methods for catchment model parameters. Hydrol. Earth Syst. Sci. J1 - HESS 9, 157-171.

Pardé, M., 1933. Fleuves et rivières. Paris, 224 pp.

Patil, S., Stieglitz, M., 2012. Controls on hydrologic similarity: role of nearby gauged catchments for prediction at an ungauged catchment. Hydrol. Earth Syst. Sci. 16, $551-562$.

Pilon, P., 2004. Guidelines for Reducing Flood Losses. United Nations, 79 p.

Pokhrel, P., Gupta, H.V., Wagener, T., 2008. A spatial regularization approach to parameter estimation for a distributed watershed model. Water Resour. Res. 44, W12419.

Rawls, W.J., Brakensiek, D.L., 1985. Prediction of soil water properties for hydrologic modelling. In: Watershed Management in the Eighties: Proceedings of the American Society of Civil ENgineers Symposium, Denver, aprol 30-May 1, 1985. ASCE, New York, pp. 293-299.

Robbez-Masson, J-M., Mazzoni, C., Vallejo, S., Ernesty, D., Falipou, P. 2002. A regional multimedia soil and landscape database on the web in order to help use and teaching of soil data. In: Presented at the 17th World Congress of Soil Science.

Roux, H., Labat, D., Garambois, P.A., Maubourguet, M.-M., Chorda, J., Dartus, D., 2011. A physically-based parsimonious hydrological model for flash floods in Mediterranean catchment. Nat. Hazards Earth Syst. Sci. J1 - NHESS 161, 2567 2582.

Ruin, I., Creutin, J.-D., Anquetin, S., Lutoff, C., 2008. Human exposure to flash floods relation between flood parameters and human vulnerability during a storm of September 2002 in Southern France. J. Hydrol. 361, 199-213.

Samaniego, L., Bardossy, A., 2005. Robust parametric models of runoff characteristics at the mesoscale. J. Hydrol. 303, 136-151.

Singh, S.K., Bárdossy, A., 2012. Calibration of hydrological models on hydrologically unusual events. Adv Water Resour. 38, 81-91.
Sivapalan, M., Takeuchi, K., Franks, S.W., Gupta, V.K., Karambiri, H., Lakshmi, V., Liang, X. McDonnell, J.J., Mendiodo, E.M., O'Connell, P.E., Oki, T., Pomery, J.W., Schertzer, D., Uhlenbrook, S., Zehe, E., 2003. IAHS decade on prediction in ungauged basins (PUB), 2003-2012: shaping an exciting future for the hydrological sciences. Hydrol. Sci. J./Journal des Sciences Hydrologiques 48, $857-880$.

Smith, T., Marshall, L.A., Sharma, A., 2014. Predicting hydrologic response through a hierarchical catchment knowledgebase: A BAyes empirical Bayes Approach. WRR.

Tramblay, Y., Bouvier, C., Martin, C., Didon-Lescot, J.-F., Todorovik, D., Domergue, J.M. 2010. Assessment of initial soil moisture conditions for event-based rainfall-runoff modelling. J. Hydrol. 387, 176-187.

Vandewiele, G.L., Elias, A., 1995. Monthly water balance of ungauged catchments obtained by geographical regionalization. J. Hydrol. 170, 277-291.

Vannier, O., Braud, I., Anquetin, S., 2013. Regional estimation of catchment-scale soil properties by means of streamflow recession analysis for use in distributed hydrological models. Hydrol. Process. n/a-n/a.

Vélez, J.J., Puricelli, M., López Unzu, F., Francés, F., 2009. Parameter extrapolation to ungauged basins with a hydrological distributed model in a regional framework. Hydrol. Earth Syst. Sci. J1 - HESS 13, 229-246.

Vieux, B.E. Cui, Z. Gaur, A., 2003. Evaluation of a physics-based distributed hydrologic model for flood forecasting. J. Hydrol. 298, 155-177.

Vincendon, B., Ducrocq, V., Saulnier, G.-M., Bouilloud, L., Chancibault, K., Habets, F., Noilhan, J., 2010. Benefit of coupling the ISBA land surface model with a TOPMODEL hydrological model version dedicated to Mediterranean flashfloods. J. Hydrol. 394, 256-266.

Viviroli, D., Mittelbach, H., Gurtz, J., Weingartner, R., 2009. Continuous simulation for flood estimation in ungauged mesoscale catchments of Switzerland - Part II: Parameter regionalisation and flood estimation results. J. Hydrol. 377, 208-225.

Wagener, T. Wheater, H.S., 2006. Parameter estimation and regionalization for continuous rainfall-runoff models including uncertainty. J. Hydrol. 320 (1-2), 132-154. http://dx.doi.org/10.1016/j.jhydrol.2005.07.015.

Wallner, M., Haberlandt, U., Dietrich, J., 2013. A one-step similarity approach for the regionalization of hydrological model parameters based on Self-Organizing maps. J. Hydrol. 494, 59-71.

Zoccatelli, D., Borga, M., Viglione, A., Chirico, G.B., Blöschl, G., 2011. Spatial moments of catchment rainfall: rainfall spatial organisation, basin morphology, and flood response. Hydrol. Earth Syst. Sci. 15, 3767-3783. 